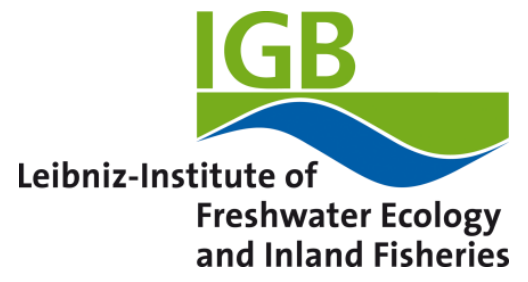

\title{
Synthesizing redox biogeochemistry at aquatic interfaces
}

Maximilian P. Lau (1) https://orcid.org/0000-0002-0675-663X, Robert Niederdorfer, Armando SepulvedaJauregui 1 https://orcid.org/0000-0001-7777-4520, Michael Hupfer

DOI

10.1016/j.limno.2017.08.001

Original publication date

27 October 2017 (Available online)

Document version

Accepted manuscript

Published in

Limnologica

Citation (Vancouver)

Lau MP, Niederdorfer R, Sepulveda-Jauregui A, Hupfer M. Synthesizing redox biogeochemistry at aquatic interfaces. Limnologica. 2018;68:59-70. 


\title{
Synthesizing redox biogeochemistry at aquatic interfaces
}

\author{
Authors: \\ Maximilian Peter Lau ${ }^{1}$, \\ Robert Niederdorfer ${ }^{2}$, \\ Armando Sepulveda-Jauregui ${ }^{3}$, \\ Michael Hupfer ${ }^{1}$
}

1: Leibniz Institute of Freshwater Ecology and Inland Fisheries, Department of Chemical Analytics and Biogeochemistry, Mueggelseedamm 301, 12587 Berlin, Germany

2: University of Vienna, Department of Limnology and Bio-Oceanography, Althanstrasse 14, 1090 Vienna, Austria

3: University of Magallanes (UMAG), Institute of Patagonia, Av. Manuel Bulnes 01890, Punta

Arenas, Chile

\section{Keywords:}

Aquatic redox chemistry

Thermodynamics

Microbial ecology

Microbial respiration

Sediments

Biofilms

\section{Abstract:}

The exchange of matter and energy between confined components of aquatic ecosystems requires the passage through their interfaces. This passage is characterized by rapid changes in physical, chemical and biological conditions and often triggers chemical transformations that involve the exchange of electrons: redox reactions. Over the last decades, research in aquatic biogeochemistry has resulted in many new but conceptually isolated findings that, together, frame an emergent view on the overarching principles of aquatic redox processes. A thermodynamic assessment may reveal the maximum available energy from such redox reactions. However, this energy can rarely be released due to various morphological, ecological and kinetic constrains on the turnover reactions. As these constrains set the boundary conditions for aquatic ecosystem functioning, they deserve particular attention in freshwater research. Here, we illustrate how physical and structural traits shape a complex redox environment and how this environment ultimately exercises control on the inhabiting microbial community and its metabolism. This aquatic microbiome is the key entity of material turnover. At the same time, the biome possesses the capability to feed back on its environment by shaping the local redox conditions and sustain niche existences. We discuss current and emerging ideas of how 
microorganisms engineer their environment, affecting aquatic redox reactions. In total, we examine this feed-back cycling between the physical environment and its colonizing biome to encourage the reader to take on the redox perspective when analyzing processes at aquatic interfaces. Understanding electron fluxes on both temporal and spatial scales is essential for the overall comprehension of matter and energy fluxes through freshwater environments. We pinpoint the methodological frontiers that will need to be challenged in future studies of aquatic redox processes. An improved mechanistic understanding will be instrumental in estimating sink and source properties of aquatic ecosystems. 


\section{Introduction}

Biogeochemical cycling of inorganic and organic material in freshwater ecosystems involves the exchange of electrons between chemical species across the interfaces between system components. This exchange of electrons in redox reactions does not only control chemical speciation but also the mobility, bioavailability and toxicity of dissolved and particulate substances (Tratnyek et al., 2011). Any redox reaction is the sum of two half reactions, the oxidation of the reductant and the reduction of the oxidant that are inter-aligned by the transfer of electrons. A redox reaction is accompanied by a change in the system's free energy. The difference in Gibb's free energy $(\Delta \mathrm{G})$ of reactants to products indicates if the reaction is thermodynamically favorable (Megonigal et al., 2003). If $\Delta \mathrm{G}$ is negative (< 0) the reaction can run spontaneously (i.e., without the addition of energy). Microorganisms overcome the kinetic limitation of reactions between chemical species that are not in equilibrium. The chemical energy released by the redox reaction may also be utilized by heterotrophic organisms (Schlesinger, 2005). Heterotrophs are critical mediators for matter turnover in many ecosystems because they couple the oxidation of organic carbon to the reduction of extracellular, terminal electron acceptors (TEA) in their respiratory activity. They ultimately aim for the formation of adenosine triphosphate by substrate level phosphorylation and electron transport phosphorylation. The net energy microorganisms may acquire in this process is a combination of the energy freed in the electron donating half-reaction and the electron accepting half reaction (LaRowe and Van Cappellen, 2011). Competition within microbial communities prompts for efficient energy conversion, favoring the usage of the TEA with the highest reduction potential $\left(E_{h}\right)$ available (Megonigal et al., 2003). However, natural reactions are confined to the Ehrange from water's reduction- to oxidation endpoint-products, hydrogen and oxygen (Grundl et al., 2011). The decrease in standard $E_{\mathrm{h}}$ of the most common TEA species from $\mathrm{O}_{2}$ via $\mathrm{NO}_{3}{ }^{-}, \mathrm{Mn}(\mathrm{IV})$ and $\mathrm{Fe}(\mathrm{III})$ minerals to $\mathrm{SO}_{4}{ }^{2-}$, is often reproduced in the temporal and/or spatial succession of microbial redox processes (Champ et al., 1979). That succession model is commonly referred to as the 'redox ladder' and key framework to understand the geomicrobiological processes in environments that are not in equilibrium.

Such thermodynamic dis-equilibria occur, for example, in depositional environments (e.g. freshwater and marine sediments) where the downward flux of organic carbon (previously fixed in primary 
production) constantly introduces energy to the system and fuels biogeochemical turnover. Many local to global biogeochemical cycles are dependent on this spatial decoupling of the zones that are either autotrophic (i.e., dominated by primary production) or heterotrophic (dominated by respiration). Interfaces between these (and other) compartments of aquatic environments are areas of steep physical, chemical or biological gradients. Matter and energy (in the form of e.g. light, temperature or electrons) that traverses aquatic interfaces set the boundary conditions for the functioning of aquatic ecosystem. Understanding electron transport dynamics across interfaces is thus of extraordinary relevance for freshwater sciences.

In this review we discuss what is currently known about respiration-induced redox processes at aquatic interfaces. We specifically address interfaces, as they are identified to be the critical sites for turnover and biodiversity. Many factors including the physical conditions, availability of nutrients and electron acceptors and community dynamics exercise control on the spatial and temporal activity-distribution of the redox reactions. Contributions to this subject have come from a wide range of disciplines. However, little synthesis between these contributions has been achieved.

We organized this multidisciplinary review around a conceptual framework that reflects the feedbacks between redox environments and associated microbial communities: We begin our discussion by examining what is known about the factors that define the redox environment at aquatic interfaces (Chapter 2). We follow this with a review of the active controls (Chapter 3) on, and the resulting structure of the microbial community at these interfaces (Chapter 4). Finally we discuss how that community, at the same time, shapes its own redox environment (Chapter 5) to sustain optimum conditions for growth. This feedback cycle gains momentum through the continuous supply of energy (mainly via allochthonous organic matter, OM), keeping the system in dis-equilibrium.

The subject of environmental redox processes has certainly been reviewed by others (e.g. Borch et al., 2010); here, however, we explicitly address process studies in the freshwater sciences. By examining how microbial communities shape and are shaped by redox conditions of their surrounding habitat, we discuss the thermodynamic and kinetic constrains on microbial processes, as such constrains may give us insight in the organizing principles of aquatic ecosystems. Clearly, resource limitation directs the 
attention of researchers towards fields of particular global relevance (as e.g. greenhouse gas emissions). Lately, such efforts presented significant amendments to the current perception of redox processes at aquatic interfaces, some of which we discuss in greater detail. In this paper, we argue that rigorous application of the underlying, novel (redox) concepts allow for advances across much wider areas of the freshwater sciences, and wish to project some of the current frontiers that may thus be breached.

\section{The benthic redox environment}

The sediment surface that encloses the water body is potentially the most important aquatic interface and a critical zone for microbial turnover in any aquatic environment. Volumetric bacterial abundance in the sediment exceeds that of the water column by up to three orders of magnitude (Schmidt et al., 1998). The benthic space hosts a disproportionate share of aquatic microorganisms, so that the physical characteristics of that space are of great importance for the major share of microorganisms at the sediment/water interface. Despite that importance, solid phases in sediments are structurally more diverse than generally acknowledged. Microorganisms cover only minor parts of the available surface area (fertile soils: about 1\%, Young et al., 2008), so that microbial distribution patterns may be critically affected by the microtopography and redox properties of the solid phases. Therefore, this chapter deals with the emerging appreciation of the redox characteristics of solid phases in benthic environments.

Generally, the physical conditions that exercise control on the microbiome are, among others, $\mathrm{pH}$, porosity, accessible surface area, salinity, abundance of nutrients and toxins and redox conditions (Horner-Devine et al., 2004). The redox conditions are commonly specified by $\mathrm{E}_{\mathrm{h}}$ measurements. Despite the popularity across freshwater scientists, the significance of measured $E_{h}$ values is constrained by two critical limitations. First and foremost, chemical species are rarely in equilibrium with each other so that the $E_{h}$ only reflects a mixed potential of species that are in electrochemical contact with the electrode (Grundl et al., 2011). Additionally, such determinations underestimate the contribution of particulate species to the bulk $E_{h}$ although it is established that particles in aquatic environments contain a range of redox-active material both in solid state or adsorbed to solid surfaces. 
These solid "geochemical" phases (Sander et al., 2015) typically contain particulate organic and mineral species as e.g. metal (oxy-)hydroxides and sulfides, calcite phases and clay minerals. Despite this structural and chemical complexity, benthic environments are regularly perceived as homogeneous and absent from participation in reactions between microorganisms and solutes. Therefore, we first discuss the emergent view of the microscopic properties of solid sedimentary phases and second, illustrate how they participate in redox reactions at aquatic interfaces. This will ultimately prepare the ground for discussing how redox conditions can then determine the active microbial community (Chapter 3).

\subsection{Structure and topology of the sediment/water interface}

Understanding the morphological features of surfaces at aquatic interfaces is fundamental to the determination of constraints on material transport and reactivity. While the benthic space in marine and freshwater environments is well characterized on a macroscopic level (e.g., Huettel et al., 2014), comparatively little is known about its structure on the sub-millimeter scale with its particular relevance for electron exchange reactions (Fig. 1).

The microtopographical features of soils and sediments that are deemed most relevant are small mesopores $(2-10 \mathrm{~nm})$; in particular because these pores are suggested to be preferential sorption sites for organic molecules (Kleber et al., 2015). For parts of the available organic matter, multisite attachment to such pores is reflected in greater adsorption and inhibited desorption when compared to a nonporous surface analogue (Mayer et al., 2004; Zimmerman et al., 2004). The role of the microtopography (cracks in minerals and pores in organics) in the formation of heterogeneous microenvironments as hotspots for specific turnover reactions is vividly discussed (Fenner et al., 2011; McClain et al., 2003; Pedersen et al., 2015). Controversies include e.g., whether or not the microbial respiration and turnover in confined soil aggregates exceeds that of bulk soil (Chenu and Cosentino, 2011; Ranjard and Richaume, 2001).

Not only does the microtopography influence surface reactivity but also the transport through the benthic space. The limitation of solute delivery clearly constrains microbial activity beyond the 
water/sediment interface. In sediments, dissolved electron acceptors are subject to dispersion and diffusion so that the transport kinetics is often ratelimiting (LaRowe et al., 2012). According to the redox ladder concept, microbial respiration beyond oxic-anoxic interfaces results in the vertical succession of redox processes. The illustration of discrete zones with definite redox reactions running is a powerful explanatory concept (LaRowe and Van Cappellen, 2011; Megonigal et al., 2003). Yet, the strictly vertical zonation in subsurface environments as a paradigm of geomicrobiology is increasingly questioned (Bethke et al., 2011; Canfield and Thamdrup, 2009). Criticism of the stratified redox zonation includes not only the small scaled physical-, but also biological heterogeneities in the sediment (Fig. 1). Both can modulate transport regimes that result in overlapping and uneven distributions of different TEA processes in the three-dimensional sediment matrix (Pedersen et al., 2015). Air filled cavities in submerged macrophytes (aerenchyma) or pumping activity of benthic macrofauna (e.g., chironomid larvae) introduces oxygen in structurally anoxic zones of the sediment (Lewandowski et al., 2007). In the rhizosphere of terrestrial environments, root networks can increase the available surface area through physical disruption and can exude inorganic and organic substances (Philippot et al., 2013). Such biological structures are additional nondiffusive vectors of electron donors and acceptors in terrestrial and presumably also aquatic environments.

\subsection{Redox biogeochemistry at the sediment/water interface}

It is well recognized that structural sediment characteristics can, for example, impose limitations on microbial species that rely on TEA delivery through interstitial solutes. Less attention, however, is directed to the microorganisms that rely on non-dissolved TEAs and how they interact with these abundant electron sinks in sediments. Dissimilatory metal reducing bacteria are among the most common examples (Nevin and Lovley, 2002; Thamdrup, 2000; Weber et al., 2006). In freshwater systems, the reactive metals $\mathrm{Fe}$ and $\mathrm{Mn}$ are widely distributed. Their stable ions exhibit broad reduction potential distributions (Gorski et al., 2012; Kluepfel et al., 2014) so that these Fe and Mn species can partake in an extensive set of aquatic redox reactions (Weber et al., 2006). 
The oxidized species Fe(III) and Mn(IV) are well known to accept electrons from microbial respiration (Lovley, 1993). The recent detection of biogenic Mn(III) species in sediments now prompts for the inclusion of this species in pore-water redox analyses (Trouwborst et al., 2006). Different mechanisms were previously identified to bridge the intracellular respiratory system to metals in the inorganic solid phase. Reduction of particulate TEA species is reported to occur with the help of organic electron transport mediators (Lovley et al., 1996; Scott et al., 1998), conductive wires at cell surfaces (Malvankar and Lovley, 2012; Reguera et al., 2005) and after dissolution of mineral surfaces by chelating agents (Brutinel and Gralnick, 2012; Marsili et al., 2008).

The mechanisms of metal reduction pathways are generally well understood. However, it remains elusive how the characteristics of the solid phases containing the metal oxy(hydroxides) constrains the electron exchange. Despite frequently assumed in protocols of iron reduction analysis in aquatic environments, many Fe-bearing minerals do not quantitatively dissolve upon reductive transformation of $\mathrm{Fe}(\mathrm{III})$ to $\mathrm{Fe}(\mathrm{II})$ (Gorski and Scherer, 2011; Lau et al., 2015b). Instead, the ferrous iron may still be adsorbed to or integrated in the mineral matrix and is thus not available for quantification as dissolved species in the sediment pore water (Gorski et al., 2013). When ferrous ions sorb to a ferric surface, valence electrons are being relocated towards sites of higher potential (Larese-Casanova and Scherer, 2007; Williams and Scherer, 2004). There, they lower the effective redox potential of the surface, rendering the use as TEA species less favorable (Handler et al., 2009). In Fe(III) minerals (including clay) both coordination and structural features influence local reduction potential so that the energy yield during the reduction of these phases can vary on micrometer scales (Bonneville et al., 2004; Gorski et al., 2013). When 2-line ferrihydrite rather than goethite is accepting electrons released in bacterial glucose mineralization, iron reduction is reported to be about $20 \mathrm{~kJ}$ (mol electrons transferred) $)^{-1}$ more exergonic (LaRowe and Van Cappellen, 2011). For these reasons, it is particularly challenging to decipher the conditions under which microorganisms exchange electrons with inorganic sediment phases. However, such knowledge is essential to predict surface charge, thus sorption characteristics and ultimately nutrient supply. 
Many freshwater systems are rich in dissolved organic matter (DOM) that is known to readily sorb onto mineral surfaces (Kaiser and Guggenberger, 2000; Riedel et al., 2013). Mineral surface topology, $\mathrm{pH}$ and residence time are the key controls on the sorptive characteristics of the mineral-water interface. DOM properties that are generally reported to increase adsorption include high hydrophobicity, large molecular size and advanced decomposition state (Kleber et al., 2015). The availability of $\mathrm{Ca}_{2+}$ ions in the dissolved phase is reported to influence mineral surface charge. By increasing positive charge at the mineralwater interface, $\mathrm{Ca}_{2+}$ ions thus promote the adsorption of $\mathrm{OM}$ to goethite (Weng et al., 2005). Adsorption to mineral surfaces has a fractionating effect on the composition of DOM (Chorover and Amistadi, 2001; Heckman et al., 2011; Riedel et al., 2012). These researchers observed preferential uptake of DOM size fractions depending on the mineral species. For instance, goethite specifically selects for the adsorption of the largest DOM fraction. These and other findings on redox properties of solid sediment phases dominate the current debate around whether adsorption on such reactive mineral surfaces promotes the oxidation (and thus degradation) of organic compounds (Blankinship et al., 2014).

Not only mineral but also organic phases at the sediment/water interface may participate in redox reactions. Similar to the redox-active metals in minerals, reactive moieties within dissolved and adsorbed OM may accept electrons from microbial respiration (Aeschbacher et al., 2010; Lovley et al., 1996). A wide range of microbial species were shown to be able to reduce OM (Cervantes et al., 2002; Martinez et al., 2013; Scheller et al., 2016). Quinone groups or condensed aromatic structures are understood to be the dominant redox active moieties in OM (Cory and McKnight, 2005; Scott et al., 1998). Due to the structural diversity of these moieties, OM features ranges of reduction potential that may largely overlap with those of Fe minerals. Reported $\mathrm{E}_{\mathrm{h}}$ values range from +0.1 to $-0.5 \mathrm{~V}$ (Kluepfel et al., 2014). This overlap is crucial for the role of dissolved OM as redox mediator in Fe reduction. Particulate OM species were also identified to be able to act as electron acceptors (Lau et al., 2015b; Roden et al., 2010). These species may be important electron sinks in environments that are deprived of other electron accepting species. In aquatic and terrestrial ecosystems, mineral and organic species are found in close spatial proximity (Eusterhues et al., 2011; Kalbitz et al., 2000; Lalonde et 
al., 2012; Riedel et al., 2013); however, it remains enigmatic, to what extend these species feature inter-phase electron exchange (Lau et al., 2016).

In conclusion, the benthic redox environment, where bacteria are considerably more abundant than in the water column (Schmidt et al., 1998), is structurally more diverse than generally acknowledged. The individual controls on the local redox environment imposed by the composition (mineral and organic phases), microtopography (pores and cracks) or reactivity (e.g., sorption dynamics) of sediments are comparatively well understood. Yet, a holistic perspective on the sedimentwater interface including the colonizing biome remains missing. Therefore, further efforts are needed to connect the structural characteristics across scales to the processes that ultimately control the spatial distribution of microbial respiration activity. In the future, this central issue may be overcome using analysis methodology with higher resolution in the temporal and spatial dimension (Pedersen et al., 2015). Only then, we can acknowledge the true role of the reaction space to microbial ecology.

\section{Redox conditions structure microbial communities}

The principles by which the external environment exercises control on the composition and size of the microbial community are an ongoing matter of research (Lennon and Cottingham, 2008; Vrede, 2005). Prominent regulators for this control include resource availability (organic matter, nutrients) and physicochemical conditions (e.g. salinity, temperature). Changes in these regulators induce large responses in the microbial community structure, as often reported in soil and marine environments (Ducklow, 2008). In ecology, the constraints that community composition imposes on ecosystem functioning are extensively discussed. Commonly, the debate encompasses the possibilities that the microbial community is either resistant to change, resilient (that is, quickly returning to its original state) or, in case of change, functionally similar. Increasing evidence supports the notion that community composition actively determines both material turnover pathways and the general functioning of aquatic environments (Comte and Del Giorgio, 2011; Reed and Martiny, 2013). Yet, to date, information on how redox conditions structure microbial communities, and therefore exercise control on ecosystem functioning, is scarce (e.g., DeAngelis et al., 2010). 
Here, we discuss how microbial communities in aquatic environments adapt to changes in redox conditions. Changes in redox conditions accompany many other disruptions (e.g. wet-dry cycles, turbulent mixing of waters) that interfere with the distribution and abundance of redox-active species in the system. From the thermodynamic perspective, the abundance of the chemical species that may be employed as electron donors or acceptors in microbial metabolism regulates the systems Gibbs free energy (LaRowe and Van Cappellen, 2011; Megonigal et al., 2003). $\Delta \mathrm{G}$ calculations based on thermodynamic input parameters help to predict the biologically catalyzed reactions (and thus the prevalent microbial species) that are to be expected (LaRowe et al., 2012). In dynamic environments, this prediction requires reactive transport models. These models incorporate not only the rates of chemical reactions but also the transport of reactant and product species to ultimately assess turnover rates. The models are commonly applied in (extreme) environments on the earth (LaRowe et al., 2008) and other planets (Marlow et al., 2014). Clearly, the availability of free energy is the strongest force that determines microbial community structure. However, $\Delta \mathrm{G}$ assessments from literature remain limited as long as their collective dependencies on the environmental (redox) conditions are unresolved (Chapter 2).

Beyond the uncertain determination of free energy, researchers propose that the composition of the microbial community that occupies a given niche is neither predetermined nor unidirectional (Postma and Jakobsen, 1996). As an example, biodiversity can alternatively be viewed as a function of dispersion when environments receive microbial inocula solely via sedimentation of particles. This uni-directional supply may explain why diversity of the microbial community decreases with the distance from the sediment surface (Hoehler and Jorgensen, 2013). More importantly though, did a chemostat experiment by Bethke et al. (2011) reveal that knowledge of the available thermodynamic energy (from the abundance of chemical species) is not sufficient to predict the composition of the microbial community. Instead, this work strongly suggests that ecological and physiological factors may be as important as thermodynamics for the regulation of microbial competition and hence community structure. This finding may help to rationalize many observations from diverse environments that, at first sight, might contradict thermodynamic principles. For example, variation of more than $85 \%$ in carbon mineralization was reported between soil samples that only received 
different microbial inocula (Strickland et al., 2009). Then, bacteria in deep sediments were shown to remain alive under extended periods of extensive starvation while, at the same time, sustaining a high density $\left(10_{3}\right.$ to $10_{8}$ cells $\left./ \mathrm{cm}_{3}\right)$ and diversity (Jørgensen, 2011; Morono et al., 2011). Finally, differences in the chemical properties of $\mathrm{OM}$ (other than higher or lower $\Delta \mathrm{G}$ values) as electron donor source were reported to exercise control on bacterial communities in freshwater lakes (Glombitza et al., 2013; Torres et al., 2011).

One common strategy to rationalize such enigmatic controls on microbial community structures is rate-limitation by fermentation, preceding the final oxidation step of organic electron donors (Jakobsen and Postma, 1999). However, some studies suggest that the classical view of a rate-limiting degradation step of the organic matter followed by a rapid final oxidation step may need overall revision (Arnosti, 2004; Brüchert and Arnosti, 2003; Pallud and Van Cappellen, 2006). In a seminal paper, Schmidt et al. (2011) reported that the rapid destabilizations of long-standing stocks of soil OM can neither be explained by the chemical structure nor the free energy. A subset of the alternative triggers that these researchers identified (co-metabolism, sorptive stabilization, physical heterogeneity) may also apply to aquatic environments.

The notion that not only contemporary but also historic environmental conditions affect the community structure and function has recently received increasing attention (Strickland et al., 2009). Examples of historic redox fluctuations include a study by Peralta et al. (2013) reporting that the drying-flooding history in wetlands constrained $\mathrm{N}$ cycling functions of the resulting microbial communities. Past shifts of redox gradients in lakes are known to be retained in DNA or other chemical parameters of sediment archives (Wunderlin et al., 2014).

In conclusion, we argue that thermodynamic assessments may help to predict microbial responses to changes in the redox environment but are unlikely to be the single determining factor. Especially at low energy yield conditions, a closer look at other system parameters might be appropriate (LaRowe et al., 2012). Hence, understanding microbial diversity and ecosystem functioning in aquatic environments requires advances in both - microbial ecology as well as thermodynamics. 


\section{Aquatic microbial communities and their versatility in energy}

\section{acquisition tactics}

Sediments are identified to be more phylogenetically diverse than any other environment type (Lozupone and Knight, 2007). In the above chapters we discussed external factors (including redox conditions) that exercise control on the microbial diversity in aquatic environments. This chapter then addresses the diversity in redox processes that these microorganism use to catalyze biogeochemical transformation (Fig. 2). In the last two decades, novel genomic and molecular methodologies significantly advanced the understanding of microbial community structures in the environment (Horner-Devine et al., 2004; Zinger et al., 2012). Through these efforts, an increasing number of species were shown to operate on previously unrecognized microbial pathways.

In many cases, the novel species or metabolic strategies are discovered at or close to aquatic interfaces because these areas offer thermodynamic opportunities and rapid dynamics that secure the generation of habitable niches for specialists (McClain et al., 2003; Gies et al., 2014; Lau et al., 2017). Microorganisms - individually or in consortia - can couple the oxidation of organic carbon (organotrophs) or inorganic substances (chemolithotrophs) to the reduction of TEA species in order to ultimately consume the provided chemical energy. The increasing appreciation of syntrophic relationships and metabolic coupling as e.g. reported along redox gradients in freshwaters (Gies et al., 2014) warrants a novel assessment of the involved reaction pathways.

We identified three regions of frontier research on microbial energy acquisition tactics that are of particular relevance for biogeochemical redox processes in freshwater sciences. (I.) The microbiological perspective on the dynamics of methane, a potent greenhouse gas highly relevant for global carbon cycling. (II.) The enormous variety in chemical species with considerable (abiotic) reactivity towards other sedimentary species that derive from (mostly) lithotrophic metabolism and (III.), the biogeochemistry behind the bio-mediated electron transfer over centimeter distances across redox interfaces. 


\subsection{Microbial methane consumption: a case-study of process diversity}

Methane $\left(\mathrm{CH}_{4}\right)$ is the most abundant organic compound in the atmosphere and is responsible for around $20 \%$ of the global warming derived from greenhouse gases (Kirschke et al., 2013). The atmospheric $\mathrm{CH}_{4}$ concentration depends on the balance between sources and sinks in natural ecosystems (e.g. in lakes, ponds, rivers, marine environments, forest soils, peatlands, grasslands) and anthropogenic sources (e.g. landfills, wastewater, chemical industry). Currently, estimations of the net $\mathrm{CH}_{4}$ emission and concentration in the atmosphere vary widely, and feature considerable uncertainties with regard to latitude, ecosystem type and anthropogenic activity (Kirschke et al., 2013; Nisbet et al., 2014).

Biological $\mathrm{CH}_{4}$ sinks exhibit large uncertainties in the magnitude and occurrence of microbial $\mathrm{CH}_{4}$ oxidation processes under both aerobic and anaerobic conditions (Conrad et al., 2009; Reeburgh, 2007; Valentine, 2002). The latter represent the most enigmatic $\mathrm{CH}_{4}$ oxidation processes, because there are vast gaps in the knowledge of system thermodynamics, turnover rates and the involved intermediates and microbial species (Joye, 2012; Thauer, 2010). Anaerobic oxidation of methane $(\mathrm{AOM})$ was previously demonstrated to be coupled to the reduction of inorganic electron acceptors like sulfates (Hallam et al., 2004; Hinrichs and Boetius, 2003; Holler et al., 2011; Moran et al., 2008; Valentine and Reeburgh, 2000; Zehnder and Brock, 1980), nitrates/ nitrites (Deutzmann et al., 2014; Ettwig et al., 2010; Haroon et al., 2013; Islas-Lima et al., 2004; Raghoebarsing et al., 2006), Fe(III) and Mn(IV) (Beal et al., 2009; Nordi et al., 2013; Segarra et al., 2013; Sivan et al., 2011) and chlorite $\left(\mathrm{ClO}_{2}{ }^{-}\right)$(Miller et al., 2014). Furthermore, an alternative AOM pathway using redox-active organic compounds as electron sink has been demonstrated recently (Scheller et al., 2016).

From a thermodynamic perspective, AOM processes releases energy with a standard $\Delta \mathrm{G}$ ranging from -14 to $<-930 \mathrm{~kJ} \mathrm{~mol}^{-1}$ of $\mathrm{CH}_{4}$ (Beal et al., 2009; Thauer and Shima, 2008; Valentine and Reeburgh, 2000). Moreover, AOM processes have several kinetic limitations compared to their aerobic counterpart. In the latter case, $\mathrm{O}_{2}$ breaks the $\mathrm{H}_{3} \mathrm{C}-\mathrm{H}$ bond, resulting in the oxidation of $\mathrm{CH}_{4}$ to methanol $\left(\mathrm{CH}_{3} \mathrm{OH}\right.$, first step in the aerobic oxidation of methane to $\left.\mathrm{CO}_{2}\right)$. In contrast, the mechanism behind the oxidative cleavage of the $\mathrm{H}_{3} \mathrm{C}-\mathrm{H}$ bond in the absence of $\mathrm{O}_{2}$ is not fully understood. Hence, specific 
AOM pathways are still a subject of theoretical thermodynamics (Caldwell et al., 2008; Hinrichs and Boetius, 2003; Valentine and Reeburgh, 2000). Consequently, Thauer and Shima (2008) pointed out that until the principals of AOM pathways are tested in pure grown cultures, all gathered evidence in support of AOM will remain circumstantial. Efforts to isolate the AOM microbiota are, to date, limited to a singular identification of the associated bacteria that partner in one specific AOM consortium (Wegener et al., 2015). However, many different AOM respiration mechanisms are discussed:

\subsubsection{AOM electron sinks: (a) sulfate}

AOM coupled to sulfate reduction (AOM-SR) was the AOM process first postulated (Barnes and Goldberg, 1976; Marterns and Berner, 1974). It was suggested that it is carried out via reverse methanogenesis or methylogenesis (Hallam et al., 2004; Moran et al., 2008; Valentine and Reeburgh, 2000) that involves a consortium of anaerobic methanotrophic archaea (ANME groups) and sulfatereducing bacteria. Recently, Milucka et al. (2012) proposed an alternative AOM-SR pathway carried out by the ANME alone. Globally, AOM-SR is identified to be an important process in sediments that may consume up to $90 \%$ of the $\mathrm{CH}_{4}$ produced by methanogens in both marine and freshwater ecosystems (Beal et al., 2011; Holler et al., 2011; Segarra et al., 2015; Timmers et al., 2015).

\subsubsection{AOM electron sinks: (b) reactive metals}

$\mathrm{Fe}(\mathrm{III})$ and $\mathrm{Mn}(\mathrm{IV})$ were recently demonstrated to directly or indirectly accept electrons released in AOM (Beal et al., 2009; Sivan et al., 2011). Reduction of these TEA species are more energetically favorable than sulfate reduction, yet more challenging to accurately quantify as both processes may be coupled, co-occurring or competing (Beal et al., 2011; Egger et al., 2015; Segarra et al., 2013; Sivan et al., 2014). Apparently, metal reduction is linked to AOM in a syntrophic process that includes species from ANME groups and Marine Benthic Group D (Beal et al., 2009). Ecologically, AOM with oxidized metals as TEA is shown to be of high relevance in the open ocean and as well as freshwater and brackish ecosystems (Segarra et al., 2013). Yet, further research is warranted to address the relevance in the global $\mathrm{CH}_{4}$ budget. 


\subsubsection{AOM electron sinks: (c) nitrogen oxides}

AOM coupled to the reduction of nitrogen oxides (denitrification, AMO-D) is well studied and the AOM pathway with the highest thermodynamic energy yield (Standard Gibbs free energy, $\Delta \mathrm{G}^{\prime}{ }^{\prime}=-928$ $\mathrm{kJ} \mathrm{mol}_{-1} \mathrm{CH}_{4}$; Raghoebarsing et al., 2006). Initial evidences regarding process stoichiometry and the involved microorganisms were presented in a sludge denitrifying reactor and in a freshwater canal (Islas-Lima et al., 2004; Raghoebarsing et al., 2006). The latter team of researchers suggested that AOM-D is carried out by an association of bacteria and archaea, but, further studies from the same lab indicated that AOM-D may also be carried out in the absence of archaea (Ettwig et al., 2008; Ettwig et al., 2009). These researchers postulated a further AOM-D pathway that relies on anoxic $\mathrm{O}_{2}$ production from $\mathrm{NO}_{2}^{-}$, carried out by a proposed bacterium now commonly referred to as Candidatus Methylomirabilis oxyfera (Ettwig et al., 2010). Since then, considerable attention was directed towards AOM-D initiated by M. oxyfera. Nevertheless, Haroon et al. (2013) described a further AOM-D pathway carried out solely by archaea ANME (ANME-2d) using $\mathrm{NO}_{3-}$ as electron acceptor via reverse methanogenesis. In a cooperative process with an anaerobic ammonium oxidizing bacteria these archaea species reduce $\mathrm{NO}_{2}{ }_{2}{ }_{-}$-to $\mathrm{N}_{2}$. AOM-D was reported to be the major methane oxidation pathway in freshwater ecosystems that feature high abundance in $\mathrm{NO}_{3^{-}}^{-}$-(Deutzmann et al., 2014; Hu et al., 2014; Nordi and Thamdrup, 2014). These researchers suggested that AOM-D primarily occurs close to the sediment-water interface in close proximity to the aerobic oxidation of $\mathrm{CH}_{4}$ (which consumes around $50 \%$ of the produced $\mathrm{CH}_{4}$ ). Clearly, further research on a fine spatial resolution is necessary to confine the contributions of oxic and anoxic reaction routes to $\mathrm{CH}_{4}$ consumption in freshwater sediments.

\subsubsection{AOM electron sinks: (d) organic compounds}

Redox active moieties within OM have also been proposed as electron acceptors coupled to AOM (Smemo and Yavitt, 2011). These moieties are identified to be re-generable redox reactive species commonly found in OM from freshwater ecosystems like peatlands and lakes sediments (Kluepfel et al., 2014; Kritzberg and Ekstrom, 2012). AOM coupled to organic compounds was originally proposed to rationalize the anaerobic respiration with reductive degradation of organic compounds 
other than $\mathrm{CH}_{4}$ (Cervantes et al., 2008; Scott et al., 1998). However, two recent studies showed that AOM can be coupled to OM reduction (AOM-O) by extracellular electron transfer in a syntrophic mechanism (Scheller et al., 2016; Valenzuela et al., 2017). This new finding is in line with many previous works that reported the use of redox-active moieties in humic substances (i.e., a refractory fraction of OM) as electron acceptors in AOM (Blodau and Deppe, 2012; Gupta et al., 2013; Smemo and Yavitt, 2007; Smemo and Yavitt, 2011). Together, AOM-O is crucial to understand $\mathrm{CH}_{4}$ emission patters from ecosystems rich in organic matter. As AOM-O is also proposed to competitively suppress methanogenesis (Kluepfel et al., 2014) it remains enigmatic to what extend AOM-O or any other AOM process contributes to $\mathrm{CH}_{4}$ balances from these ecosystems.

\subsection{Biotic-abiotic reaction coupling drives diversity in electron exchange reactions}

In chemolithotrophic microorganisms, energy metabolism is uncoupled from organic carbon supply. Here, the oxidation of inorganic substrates is linked to the reduction of a TEA species and the released energy may subsequently be used in the fixation of $\mathrm{C}$ compounds (e.g. $\mathrm{CO}_{2}$ ). Well described chemolithotrophic pathways include the oxidation of e.g. $\mathrm{NH}_{4}^{+}, \mathrm{NO}_{2}{ }^{-}, \mathrm{Fe}(\mathrm{II}), \mathrm{H}_{2} \mathrm{~S}$ or $\mathrm{S}_{0}$ with $\mathrm{O}_{2}$ (Schlesinger, 2005). The involved species typically inhabit environments close to redox interfaces (sediment-water interface, soil aggregates, biofilms) where gradients of the reductant and oxidant (mostly $\mathrm{O}_{2}$ ) are overlapping and the convective or diffusive transport conditions limit the supply of the redox partners. Methodological advances have allowed researchers to detect previously unrecognized microbial dissimilatory processes. As an example, $\mathrm{S}$ and $\mathrm{Fe}$ oxidizing bacteria in freshwater ecosystems are suspected to also use $\mathrm{NO}_{3}$ - as oxidant (Blöthe and Roden, 2009; Payne et al., 2009). However, it is and remains challenging to separate biotic from abiotic redox mechanisms; in the latter case for example, chemical oxidation of $\mathrm{Fe}$ (II) by $\mathrm{NO}_{2}^{-}$(an intermediate species formed e.g. in denitrification) competes with microbial Fe(II)oxidation (Klueglein and Kappler, 2013).

In general, $\mathrm{Fe}(\mathrm{II}) \mathrm{Fe}(\mathrm{III})$ redox reactions are reported to run on many different abiotic and microbial mediated pathways (see the comprehensive review by Melton et al., 2014) and led to the hypothesis of a "ferrous wheel", initially brought forward by Davidson et al. (2003). While these and other 
researchers focused on the relevance of previously unrecognized oxidation-reduction reactions that involve Fe and redox active organic species (Weber et al., 2006), amendments to the hypotheses now propose that possibly many more biogeochemical reactions in the subsurface may be coupled to $\mathrm{Fe}$ redox chemistry ( $\mathrm{Li}$ et al., 2012). Common examples include the close links between $\mathrm{Fe}$ and sulfur redox chemistry in aquatic ecosystems (Rickard and Luther, 2007). Sulfide-oxidizing reactions are central to the habitability of many subsurface environments due to the toxicity of hydrogen sulfide. Fe- sulfide minerals are reported to be the major sinks of reduced $\mathrm{S}$ in anaerobic environments (Rickard and Morse, 2005). Consequently, S transformation between (mobile) aqueous and solid phases is controlled by $\mathrm{Fe}$ (oxyhydr-)oxides in two ways. First, ferrous iron demobilizes S species through mineral formation. Mineral-surface attached polysulfides were recently suggested as important precursor species (Wan et al., 2014). And second, Fe sulfide oxidation may be coupled to Fe(III)hydroxide reduction (Poulton et al., 2004; Zopfi et al., 2008). A variety of S species of intermediate redox state was observed during the sulfide mineral oxidation (Burton et al., 2009). However, the role of these partially oxidized species in the sulfur-iron cycle remains unclear.

\subsection{Bioelectric fluxes through benthic environments}

Opposed to organotrophs, (chemo)lithotrophs capture the energy stored in reduced inorganic substances (instead of OM). By making use of reduced and oxidized substrates that are supplied from either direction at redox interfaces, both types of species realize redox reactions between reductants and oxidants through microbial (enzymatic) catalysis in loco. Hence, if in situ concentrations gradients of the respective substances do not sufficiently overlap, these areas do not provide enough free energy to sustain a microbial niche existence. In the latter case, however, microorganisms are reported to circumvent energy constrains using astonishing tactics: Extended cellular networks are reported to connect areas of electron depletion and electron surplus over centimeter distances (Nielsen et al., 2010). The resulting connection allows for the capturing of energy by short-circuiting the pools of redox species through electrical conductivity (Risgaard-Petersen et al., 2012). The microorganisms that were shown to administer this geochemical electron transport are commonly referred to as "cable 
bacteria". These species are reported to be sulfide-oxidizing microorganisms and were initially found in estuarine sediments (Pfeffer et al., 2012). Since then, further marine and also freshwater habitats were identified and manifold proof was presented that substantiated their role in directing electron fluxes through anaerobic environments (Larsen et al., 2015; Marzocchi et al., 2014; Schauer et al., 2014). Yet unidentified conductive (i.e., redox active) materials facilitate the transport across redox interfaces. The structures that are suspected to facilitate the energy-conserving charge transport between extracellular redox-active species and the intracellular catabolic/respirational apparatus include conductive mineral nanoparticles, porin-cytochrome modules and quinoid moieties (Kato et al., 2012; Nielsen et al., 2010; Richardson et al., 2012).

To conclude, geomicrobiologists have identified a wide spectrum of microbial energy acquisition tactics and ongoing efforts continue to add more detail to the types and prevalence of specific metabolic routes (Fig. 2). Current research in this rapidly developing field is particularly driven by the urge to improve projections of climate change which results in a focus on metabolic routes that involve greenhouse gases. As presented, the potent greenhouse gas methane is subject to a huge variety of redox processes and raises the expectation that the same is true for many other microbial metabolites. Thus, novel -omics analyses are fundamental to illuminate the spatial and temporal patterns in the turnover of methane as well as any chemical species in the environment. The flux of electrons through biological systems is yet another critical endeavor that requires more research in order to resolve the diversity in species, pathways and tactics that are essential to microbial life (Burgin et al., 2011). In light of the important aquatic components of the global cycles of carbon and the nutrients $\mathrm{N}, \mathrm{P}$ and $\mathrm{S}$, further inquiries focusing on aquatic redox chemistry are warranted.

\section{Habitat optimization strategies}

Bacteria regularly access and colonize environments of less-than ideal conditions, dominated by physical forces and deficient in nutrients. Here, biofilm growth is the most common and important strategy to engineer an environment in order to thrive in a favorable niche. 
Microbial biofilms are surface-attached communities of cells embedded in a porous extracellular matrix and appear to be the oldest known microbial community assemblages (Normark, 2015). Biofilms typically dominate microbial life in aquatic ecosystems with high sediment surface area to water volume ratios and high downstream transport. Environmental biofilms can be found in tidal flats, at the bottom of most lakes, streams and rivers and in many extreme environments from frozen glaciers to hydrothermal vents (Battin et al., 2016; Smith et al., 2016). The attachment strategy extends the residence time of solutes in the microbial vicinity and thus enhances the potential for the metabolism of a substrate and the formation of interspecies consortia.

Typically, the biofilm formation is initiated through a reversible attachment of pioneering bacteria via van der Waals forces, which enables them to review the suitability of the potential microenvironment before committing to irreversible attachment to the unknown habitat (Sigee, 2005). Cell adhesion on the surface is then mediated via adhesins, which are arranged at the tip of cell surface extensions (pili). Further growth involves the production of extracellular polymeric substances and formation of larger cell clusters, which are separated by water channels to ensure nutrient availability throughout the biofilm layers (Hall-Stoodley et al., 2004). The main components of the highly hydrated extracellular matrix are polysaccharides, proteins, carbohydrates, extracellular DNA, cell compounds and water. Redox-active enzymes may be embedded in the biofilm and facilitate the vertical transport of electrons through the biofilm matrix (Marsili et al., 2008). Intra-biofilm redox gradients are observed on micrometer scale in biofilms of metal- and sulfate-reducing bacteria (Snider et al., 2012). Together, the biofilms extracellular polymeric substance provides favorable conditions for the embedded community including adhesion, protection, redox conditions and the accumulation and delivery of nutrients (Flemming and Wingender, 2010; Flemming et al., 2016).

In sediments of aquatic ecosystems, surface attached biofilms develop from the metacommunity contained in the overlying water (Besemer et al., 2012; Wilhelm et al., 2013). According to the metacommunity theory by Leibold et al. (2004), the abiotic environment, (local) biotic interactions and (regional) dispersal processes regulate the assembly of local communities in the biofilm. 
Sediments harbor rich biological communities, which are processing refractory OM and recycle nutrients (Schmidt et al., 1998).

In environments of lower surface-area to water-volume ratios and extended surface residence times as in larger rivers, reservoirs, floodplain lakes and estuarine drown valleys - microorganisms may use alternative habitat optimization strategies and, for example, form or colonize suspended aggregates. Such aggregates are long known abundant pelagic microhabitats in marine and fresh waters and feature steep gradients in redox conditions (Alldrege and Cohen, 1987; Grossart and Simon, 1993). Headwaters, in contrast, are no favorable habitats for aggregate-attached or free-living planktonic bacteria, due to turbulent flow conditions and high shear forces, which allow biofilms to exploit these areas nearly for themselves. There, microorganisms in surface-attached and matrixenclosed stream biofilms have developed multiple strategies to resist erosion (Hall-Stoodley et al., 2004). For example, biofilms can have a stabilizing effect on non-cohesive sediments in rivers, shaping the biological microenvironment where, otherwise, downwards movement of sediment would have a large effect on riverbed morphology (Vignaga et al., 2013).

Mass transport within biofilms is regulated by their structure and hydrodynamics. Biofilm structure, however, is highly dependent on the external flow conditions and nutrient availability (Stoodley et al., 1999). The supply of nutrients and OM from the bulk to the biofilm is limited by diffusion across the mass transport boundary layer above the biofilm surface (Lewandowski and Beyenal, 2007). As a result, convection below the biofilm surface may help to distribute solutes within the biofilm. Unfavorable redox conditions that arise e.g. from oxygen deficiency are reported to induce biofilm dispersal (McDougald et al., 2012). Biofilms also exhibit surface heterogeneities and pores so that convective transport in and through the extracellular matrix may allow a deeper penetration of nutrients into the biofilm. As such, redox conditions within the biofilm (that reflect the chemical equilibria of the present species) are expected to be highly complex and structured on micrometer scales. However, little is known about the actual conditions and spatiotemporal distribution of redox species in biofilms (Pedersen et al., 2015). As an analogy, while disparate in scale, bulk sediment and biofilms are exhibiting striking morphological similarities. Both can be characterized as porous media 
with advective and diffusive mass transfer and steep internal, chemical and biological, gradients (Battin et al., 2016). The three-dimensional architecture (i.e., physical structure) of biofilms can also change the hydrodynamic microenvironment around the biofilms and creates transient storage opportunities at the microscale (Battin et al., 2003; Bottacin-Busolin et al., 2009; Freeman and Lock, 1995). To enlarge the bioreactive surface area and to enhance the uptake of solutes and particles while avoiding scour, biofilms often develop filamentous streamers floating in the bulk liquid (Besemer et al., 2007; Hall-Stoodley et al., 2004).

Collectively, these observations suggest that biofilms can be seen as ecological interfaces in aquatic environments, affecting and affected by hydrodynamic conditions, light availability and nutrient cycling (Battin et al., 2016). Biofilms operate as interfaces for solute exchange and biological interactions in fluvial ecosystems (Cadenasso et al., 2003; Strayer et al., 2003) and recent studies have underlined their importance in these ecosystems as they contribute largely to the carbon cycle, degrading refractory $\mathrm{OM}$ and emitting large amounts of carbon dioxide (Battin et al., 2008). The enclosed microbiome orchestrates large-scale biochemical fluxes such as the nitrogen cycle of streams (Mulholland et al., 2008) and they are indicators of freshwater ecosystem health (Lau et al., 2015a).

Several studies on biofilms, their role in the functioning and in the shaping of freshwater ecosystems have been published within the last years. However, despite their fundamental relevance, the key functional capabilities of biofilms, their role in directing ecosystem energy and matter fluxes and, especially, the intrinsic redox biogeochemistry need further attention in ecology.

\section{Synthesis}

This work outlines the growing appreciation of the many of degrees of freedom chemical reactions in aquatic ecosystems are subject to. Benthic environments, including sediments and surface-attached biofilms, offer subtle spatiotemporal differences in redox conditions that ultimately exercise control on the availability of thermodynamic energy. The majority of past studies across the wide field of aquatic redox chemistry circumstantiate that any energetically niche is eventually occupied and preserved by a specialized species (or consortium of species) that ultimately makes use of the available energy. The 
underlying mechanisms, however, remain controversial as microbial ecologists are only beginning to acknowledge the coupled physical and chemical conditions that constrain microbial community structure and function.

Significant theoretical and practical constrains have, until recently, hindered the comprehensive study of electron fluxes through aquatic environments. These constrains include the scaling of submicrometer features of sediment surfaces, the appreciation of the latter's redox properties (Fig. 1), the staggering diversity in microbial energy acquisition tactics (Fig. 2) and the difficulties in defining the niches those microbial species inhabit or create in the first place.

This last point has been particularly problematic in studies of redox processes at aquatic interfaces. There and elsewhere, thermodynamics are the most powerful framework to predict energetic opportunities. Thermodynamic calculations can, however, only be as accurate as their input parameters, and defining boundary conditions is notoriously challenging in natural systems. The result of this uncertainty is, of course, a lack in the understanding of community responses in dynamic environments as regularly found in freshwater systems. Biogeochemists and microbial ecologist have become increasingly interested in bridging the gap between these disciplines and resolve the additional controls on microbial ecology. To date, these controls include for example dispersion, reactioncoupling, co-metabolism and exceptional physiological traits of specialized species. Collectively, organism adaption processes appear to be a key study subject to reach a coherent understanding of biophysical interface processes at the smallest scale.

The current lack in appropriate up-scaling methodologies impedes the incorporation of the small-scale biogeochemical processes into large-scale descriptions, and insufficient knowledge on biophysical interfaces was suggested to delay e.g. the development of ecologically appropriate management strategies in aquatic environments (Marion et al., 2014). A fully developed mechanistic understanding of microbial turnover at interfaces would therefore be instrumental to aquatic sciences across scales and disciplines. We argue that aquatic redox chemistry represents a common framework that facilitates researchers from diverse backgrounds to collectively join the debate on interface processes. We now 
have the tools and understanding necessary to map the flow of matter and energy through freshwater environments. We envision four areas that we deem particularly fruitful to close knowledge gaps.

Firstly, research designed to increase our understanding of how usable $\Delta \mathrm{G}$ of electron donating- and accepting species vary in natural conditions are likely to be fruitful. Such research has played a major role in understanding the thermodynamic driving force, how it affects community composition along environmental gradients and how it can lend insight into basic processes such as microbial speciation, activity and turnover that are harder to study in situ. In addition, understanding thermodynamic, kinetic and ecologic controls on microbial biodiversity will aid in appropriately projecting community composition in low energy environments (Hoehler and Jorgensen, 2013; Lever et al., 2015).

Secondly, the recent advances in the -omics research could help to better understand the role of microbial diversity for the functioning of aquatic ecosystems. More research towards yet unknown enzymatic pathways and microbial entities is warranted, may help closing the gap between laboratory and field investigations and may possibly proof useful in other, more applied disciplines (Marx, 2017).

Thirdly, an understanding of the topology and reactivity of surfaces in aquatic environment is fundamental; such efforts are underway in various research groups. The availability of synchrotronbased methods has revolutionized the ability to map chemical composition (Kellerman et al., 2014). Field investigations, in contrast, profit from the development of microsensors and -optodes in everdecreasing dimensions. These techniques can describe chemical gradients and resolve spatial and temporal heterogeneity at unprecedented levels (Pedersen et al., 2015). However, it remains a key challenge to connect the physical environment with the colonizing biome on such scales and the contemporary methods for this connection (e.g., nano-secondary ion mass spectrometry, nanoSIMS and Raman spectroscopy, Wagner, 2009) will need to be applied more rigorously.

Finally, in a plea for more reliant estimates of global biogeochemical cycles it was concluded that "data without models are chaos, but models without data are fantasy" (Nisbet et al., 2014). Although recent studies have begun to incorporate novel perspectives on aquatic redox processes in modeling approaches, further efforts are deemed necessary given the critical importance of these processes to the functioning of aquatic ecosystems. 


\section{Acknowledgements:}

We explicitly acknowledge the fruitful atmosphere within the AQUALINK graduate school that prepared the ground for the realization of this article. We further thank Jenny Fabian and Jörg Gelbrecht for valuable discussions. We thank two anonymous reviewers for incredibly helpful comments and suggestions.

The authors declare no competing financial interest. Funding was provided by the Leibniz Assoziation (SAW 2012 IGB4167) and Deutsche Forschungsgemeinschaft, DFG (Redoxphos HU 740/5-1).

\section{References:}

Aeschbacher, M., Sander, M., Schwarzenbach, R.P., 2010. Novel electrochemical approach to assess the redox properties of humic substances. Environ. Sci. Technol. 44, 87-93.

Alldrege, A.L., Cohen, Y., 1987. Can microscale chemical patches persist in the sea? Microelectrode study of marine snow, fecal pellets. Science 235, 689-691. http://dx.doi.org/10.1126/science.235.4789.689.

Arnosti, C., 2004. Speed bumps and barricades in the carbon cycle: substrate structural effects on carbon cycling. Mar. Chem. 92, 263-273. http://dx.doi.org/10.1016/j.marchem.2004.06.030.

Barnes, R.O., Goldberg, E.D., 1976. Methane production and consumption in anoxic marinesediments. Geology 4, 297-300.

Battin, T.J., Kaplan, L.A., Denis Newbold, J., Hansen, C.M.E., 2003. Contributions of microbial biofilms to ecosystem processes in stream mesocosms. Nature 426, 439-442. http://dx.doi.org/10.1038/nature02152.

Battin, T.J., Kaplan, L.A., Findlay, S., Hopkinson, C.S., Marti, E., Packman, A.I., Newbold, J.D., Sabater, F., 2008. Biophysical controls on organic carbon fluxes in fluvial networks. Nat. Geosci. 1, 95-100. http://dx.doi.org/10.1038/ngeo101.

Battin, T.J., Besemer, K., Bengtsson, M.M., Romani, A.M., Packmann, A.I., 2016. The ecology and biogeochemistry of stream biofilms. Nat. Rev. Microbiol. 14, 251-263. http://dx.doi.org/10.1038/nrmicro.2016.15.

Beal, E.J., House, C.H., Orphan, V.J., 2009. Manganese- and iron-dependent marine methane oxidation. Science 325, 184-187. http://dx.doi.org/10.1126/science.1169984.

Beal, E.J., Claire, M.W., House, C.H., 2011. High rates of anaerobic methanotrophy at low sulfate concentrations with implications for past and present methane levels. Geobiology 9, 131-139. http://dx.doi.org/10.1111/j.1472-4669.2010.00267.x.

Besemer, K., Singer, G., Limberger, R., Chlup, A.-K., Hochedlinger, G., Hödl, I., Baranyi, C., Battin, T.J., 2007. Biophysical controls on community succession in stream biofilms. Appl. Environ. Microbiol. 73, 4966-4974. http://dx.doi.org/10.1128/aem.00588-07.

Besemer, K., Peter, H., Logue, J.B., Langenheder, S., Lindström, E.S., Tranvik, L.J., Battin,T.J., 2012. Unraveling assembly of stream biofilm communities. ISME J. 6,1459-1468. http://dx.doi.org/10.1038/ismej.2011.205. 
Bethke, C.M., Sanford, R.A., Kirk, M.F., Jin, Q., Flynn, T.M., 2011. The thermodynamic ladder in geomicrobiology. Am. J. Sci. 311, 183-210.

Blöthe, M., Roden, E.E., 2009. Composition and activity of an autotrophic Fe(II)-oxidizing, nitratereducing enrichment culture. Appl. Environ. Microbiol. 75, 6937-6940.

http://dx.doi.org/10.1128/aem.01742-09.

Blankinship, J.C., Becerra, C.A., Schaeffer, S.M., Schimel, J.P., 2014. Separating cellular metabolism from exoenzyme activity in soil organic matter decomposition. Soil Biol. Biochem. 71, 68-75. http://dx.doi.org/10.1016/j.soilbio.2014.01.010.

Blodau, C., Deppe, M., 2012. Humic acid addition lowers methane release in peats of the Mer Bleue bog, Canada. Soil Biol. Biochem. 52, 96-98.

Bonneville, S., Van Cappellen, P., Behrends, T., 2004. Microbial reduction of iron(III) oxyhydroxides: effects of mineral solubility and availability. Chem. Geol. 212, 255-268. http://dx.doi.org/10.1016/j.chemgeo.2004.08.015.

Borch, T., Kretzschmar, R., Kappler, A., Cappellen, P.V., Ginder-Vogel, M., Voegelin, A., Campbell, K., 2010. Biogeochemical redox processes and their impact on contaminant dynamics. Environ. Sci. Technol. 44 (1), 15-23. http://dx.doi.org/10.1021/es9026248.

Bottacin-Busolin, A., Singer, G., Zaramella, M., Battin, T.J., Marion, A., 2009. Effects of streambed morphology and biofilm growth on the transient storage of solutes. Environ. Sci. Technol. 43, 7337-7342. http://dx.doi.org/10.1021/es900852w.

Brüchert, V., Arnosti, C., 2003. Anaerobic carbon transformation: experimental studies with flowthrough cells. Mar. Chem. 80, 171-183. http://dx.doi.org/10.1016/S0304-4203(02)00119-6.

Brutinel, E.D., Gralnick, J.A., 2012. Shuttling happens: soluble flavin mediators of extracellular electron transfer in Shewanella. Appl. Microbiol. Biotechnol. 93, 1-8.

Burgin, A.J., Yang, W.H., Hamilton, S.K., Silver, W.L., 2011. Beyond carbon and nitrogen: how the microbial energy economy couples elemental cycles in diverse ecosystems. Front. Ecol. Environ. 9, 44-52. http://dx.doi.org/10.1890/090227.

Burton, E.D., Bush, R.T., Sullivan, L.A., Hocking, R.K., Mitchell, D.R.G., Johnston, S.G., Fitzpatrick, R.W., Raven, M., McClure, S., Jang, L.Y., 2009. Iron-monosulfide oxidation in natural sediments: resolving microbially mediated $\mathrm{S}$ transformations using XANES, electron microscopy, and selective extractions. Environ. Sci. Technol. 43, 3128-3134. http://dx.doi.org/10.1021/es8036548.

Cadenasso, M.L., Pickett, S.T.A., Weathers, K.C., Bell, S.S., Benning, T.L., Carreiro, M.M., Dawson, T.E., 2003. An interdisciplinary and synthetic approach to ecological boundaries. Bioscience 53http://dx.doi.org/10.1641/0006-3568(2003)053[0717:aiasat]2.0.co;2. (717-717).

Caldwell, S.L., Laidler, J.R., Brewer, E.A., Eberly, J.O., Sandborgh, S.C., Colwell, F.S., 2008. Anaerobic oxidation of methane: mechanisms, bioenergetics, and the ecology of associated microorganisms. Environ. Sci. Technol. 42, 6791-6799. http://dx.doi.org/10.1021/es800120b.

Canfield, D.E., Thamdrup, B., 2009. Towards a consistent classification scheme for geochemical environments, or, why we wish the term 'suboxic' would go away. Geobiology 7, 385-392. http://dx.doi.org/10.1111/j.1472-4669.2009.00214.x.

Cervantes, F.J., F.a.M.D, Bok, Duong-Dac, T., Stams, A.J.M., Lettinga, G., Field, J.A., 2002. Reduction of humic substances by halorespiring, sulphate-reducing and methanogenic microorganisms. Environ. Microbiol. 4, 51-57. http://dx.doi.org/10.1046/j.14622920.2002.00258.x.

Cervantes, F.J., Gutierrez, C.H., Lopez, K.Y., Estrada-Alvarado, M.I., Meza-Escalante, E.R., Texier, A.C., Cuervo, F., Gomez, J., 2008. Contribution of quinone-reducing microorganisms to the anaerobic biodegradation of organic compounds under different redox conditions. Biodegradation 19, 235-246. http://dx.doi.org/10.1007/s10532-007-9130-x. 
Champ, D., Gulens, J., Jackson, R., 1979. Oxidation-reduction sequences in ground water flow systems. Can. J. Earth Sci. 16, 12-23. http://dx.doi.org/10.1139/e79-002.

Chenu, C., Cosentino, D., 2011. Microbial regulation of soil structural dynamics. In: Ritz, K., Young, I. (Eds.), The Architecture and Biology of Soils: Life in Inner Space.

Chorover, J., Amistadi, M.K., 2001. Reaction of forest floor organic matter at goethite, birnessite and smectite surfaces. Geochim. Cosmochim. Acta 65, 95-109. http://dx.doi.org/10.1016/S00167037(00)00511-1.

Comte, J., Del Giorgio, P.A., 2011. Composition influences the pathway but not the outcome of the metabolic response of bacterioplankton to resource shifts. PLoS One 6, e25266. http://dx.doi.org/10.1371/journal.pone.0025266.

Conrad, R., Klose, M., Noll, M., 2009. Functional and structural response of the methanogenic microbial community in rice field soil to temperature change. Environ. Microbiol. 11, 18441853. http://dx.doi.org/10.1111/j.1462-2920.2009.01909.x.

Cory, R.M., McKnight, D.M., 2005. Fluorescence spectroscopy reveals ubiquitous presence of oxidized and reduced quinones in dissolved organic matter. Environ. Sci. Technol. 39, 81428149.

Davidson, E.A., Chorover, J., Dail, D.B., 2003. A mechanism of abiotic immobilization of nitrate in forest ecosystems: the ferrous wheel hypothesis. Glob. Change Biol. 9, 228-236. http://dx.doi.org/10.1046/j.1365-2486.2003.00592.x.

DeAngelis, K.M., Silver, W.L., Thompson, A.W., Firestone, M.K., 2010. Microbial communities acclimate to recurring changes in soil redox potential status. Environ. Microbiol. 12, 31373149. http://dx.doi.org/10.1111/j.462-2920.2010.02286.x.

Deutzmann, J.S., Stief, P., Brandes, J., Schink, B., 2014. Anaerobic methane oxidation coupled to denitrification is the dominant methane sink in a deep lake. Proc. Natl. Acad. Sci. U. S. A. 111, 18273-18278. http://dx.doi.org/10.1073/pnas.1411617111.

Ducklow, H., 2008. Microbial services: challenges for microbial ecologists in a changing world. Aquat. Microb. Ecol. 53, 13-19.

Egger, M., Rasigraf, O., Sapart, C.J., Jilbert, T., Jetten, M.S.M., Rockmann, T., Van Der Veen, C., Banda, N., Kartal, B., Ettwig, K.F., Slomp, C.P., 2015. Iron-mediated anaerobic oxidation of methane in brackish coastal sediments. Environ. Sci. Technol. 49, 277-283. http://dx.doi.org/10.1021/es503663z.

Ettwig, K.F., Shima, S., Van De Pas-Schoonen, K.T., Kahnt, J., Medema, M.H., Op Den Camp, H.J.M., Jetten, M.S.M., Strous, M., 2008. Denitrifying bacteria anaerobically oxidize methane in the absence of Archaea. Environ. Microbiol. 10, 3164-3173. http://dx.doi.org/10.1111/j.1462-2920.2008.01724.x.

Ettwig, K.F., Van Alen, T., Van De Pas-Schoonen, K.T., Jetten, M.S.M., Strous, M., 2009. Enrichment and molecular detection of denitrifying methanotrophic bacteria of the NC10 phylum. Appl. Environ. Microbiol. 75, 3656-3662. http://dx.doi.org/10.1128/aem.00067-09.

Ettwig, K.F., Butler, M.K., Le Paslier, D., Pelletier, E., Mangenot, S., Kuypers, M.M.M., Schreiber, F., Dutilh, B.E., Zedelius, J., De Beer, D., Gloerich, J., Wessels, H., Van Alen, T., Luesken, F., Wu, M.L., Van De Pas-Schoonen, K.T., Den Camp, H., Janssen-Megens, E.M., Francoijs, K.J., Stunnenberg, H., Weissenbach, J., Jetten, M.S.M., Strous, M., 2010. Nitrite-driven anaerobic methane oxidation by oxygenic bacteria. Nature 464 . http://dx.doi.org/10.1038/nature08883. (543-U94).

Eusterhues, K., Rennert, T., Knicker, H., Kögel-Knabner, I., Totsche, K.U., Schwertmann, U., 2011. Fractionation of organic matter due to reaction with ferrihydrite: coprecipitation versus adsorption. Environ. Sci. Technol. 45, 527-533. http://dx.doi.org/10.1021/es1023898. 
Fenner, N., Williams, R., Toberman, H., Hughes, S., Reynolds, B., Freeman, C., 2011. Decomposition 'hotspots' in a rewetted peatland: implications for water quality and carbon cycling. Hydrobiologia 674, 51-66. http://dx.doi.org/10.1007/s10750-011-0733-1.

Flemming, H.-C., Wingender, J., 2010. The biofilm matrix. Nat. Rev. Microbiol. 8, 623-633. http://dx.doi.org/10.1038/nrmicro2415.

Flemming, H.-C., Wingender, J., Szewzyk, U., Steinberg, P., Rice, S.A., Kjelleberg, S., 2016. Biofilms: an emergent form of bacterial life. Nat. Rev. Microbiol. 14 (9), 563-575. http://dx.doi.org/10.1038/nrmicro.2016.94.

Freeman, C., Lock, M.A., 1995. The biofilm polysaccharide matrix: a buffer against changing organic substrate supply? Limnol. Oceanogr. 40, 273-278. http://dx.doi.org/10.4319/lo.1995.40.2.0273.

Gies, E.A., Konwar, K.M., Beatty, J.T., Hallam, S.J., 2014. Illuminating microbial dark matter in meromictic sakinaw lake. Appl. Environ. Microbiol. 80, 6807-6818. http://dx.doi.org/10.1128/aem.01774-14.

Glombitza, C., Stockhecke, M., Schubert, C.J., Vetter, A., Kallmeyer, J., 2013. Sulfate reduction controlled by organic matter availability in deep sediment cores from the saline, alkaline Lake Van (Eastern Anatolia, Turkey). Front. Microbiol. 4, 209. http://dx.doi.org/10.3389/fmicb.2013.00209.

Gorski, C.A., Scherer, M.M., 2011. Fe(II) Sorption at the Fe Oxide-Water Interface: A Revised Conceptual Framework. Aquatic Redox Chemistry. American Chemical Society.

Gorski, C.A., Aeschbacher, M., Soltermann, D., Voegelin, A., Baeyens, B., Marques Fernandes, M., Hofstetter, T.B., Sander, M., 2012. Redox properties of structural Fe in clay minerals: 1. Electrochemical quantification of electron donating and accepting capacities of smectites. Environ. Sci. Technol. 46, 9360-9368.

Gorski, C.A., Klüpfel, L.E., Voegelin, A., Sander, M., Hofstetter, T.B., 2013. Redox properties of structural Fe in clay minerals: 3. relationships between smectite redox and structural properties. Environ. Sci. Technol. 47, 13477-13485. http://dx.doi.org/10.1021/es403824x.

Grossart, H.P., Simon, M., 1993. Limnetic macroscopic organic aggregates (lake snow): Occurance, characteristics, and microbial dynamics in Lake Constance. Limnol. Oceanogr. 38 (3), 532 546.

Grundl, T.J., Haderlein, S., Nurmi, J.T., Tratnyek, P.G., 2011. Introduction to Aquatic Redox chemistry. American Chemical Society.

Gupta, V., Smemo, K.A., Yavitt, J.B., Fowle, D., Branfireun, B., Basiliko, N., 2013. Stable isotopes reveal widespread anaerobic methane oxidation across latitude and peatland type. Environ. Sci. Technol. 47, 8273-8279. http://dx.doi.org/10.1021/es400484t.

Hall-Stoodley, L., Costerton, J.W., Stoodley, P., 2004. Bacterial biofilms: from the natural environment to infectious diseases. Nat. Rev. Microbiol. 2, 95-108.

Hallam, S.J., Putnam, N., Preston, C.M., Detter, J.C., Rokhsar, D., Richardson, P.M., Delong, E.F., 2004. Reverse methanogenesis: testing the hypothesis with environmental genomics. Science $305,1457-1462$.

Handler, R.M., Beard, B.L., Johnson, C.M., Scherer, M.M., 2009. Atom exchange between aqueous $\mathrm{Fe}$ (II) and goethite: an Fe isotope tracer study. Environ. Sci. Technol. 43, 1102-1107. http://dx.doi.org/10.1021/es802402m.

Haroon, M.F., Hu, S.H., Shi, Y., Imelfort, M., Keller, J., Hugenholtz, P., Yuan, Z.G., Tyson, G.W., 2013. Anaerobic oxidation of methane coupled to nitrate reduction in a novel archaeal lineage. Nature 500, 567. http://dx.doi.org/10.1038/nature12375.

Heckman, K., Vazquez-Ortega, A., Gao, X., Chorover, J., Rasmussen, C., 2011. Changes in water extractable organic matter during incubation of forest floor material in the presence of quartz, 
goethite and gibbsite surfaces. Geochim. Cosmochim. Acta 75, 4295-4309.

http://dx.doi.org/10.1016/j.gca.2011.05.009.

Hinrichs, K.U., Boetius, A., 2003. The anaerobic oxidation of methane: new insights in microbial ecology and biogeochemistry. In: Wefer, G., Billet, D., Hebbeln, D., Jørgensen, B.B., van Weering, T.C.E. (Eds.), Ocean Margin Systems. Springer Berlin Heidelberg, Berlin, Heidelberg.

Hoehler, T.M., Jorgensen, B.B., 2013. Microbial life under extreme energy limitation. Nat. Rev. Microbiol. 11, 83-94.

Holler, T., Wegener, G., Niemann, H., Deusner, C., Ferdelman, T.G., Boetius, A., Brunner, B., Widdel, F., 2011. Carbon and sulfur back flux during anaerobic microbial oxidation of methane and coupled sulfate reduction. Proc. Natl. Acad. Sci. U. S. A. 108, E1484-E1490. http://dx.doi.org/10.1073/pnas.1106032108.

Horner-Devine, M.C., Carney, K.M., Bohannan, B.J.M., 2004. An ecological perspective on bacterial biodiversity. Proc. R. Soc. Lond. B: Biol. Sci. 271, 113-122. http://dx.doi.org/10.1098/rspb.2003.2549.

Hu, B.-L., Shen, L.-D., Lian, X., Zhu, Q., Liu, S., Huang, Q., He, Z.-F., Geng, S., Cheng, D.-Q., Lou, L.-P., Xu, X.-Y., Zheng, P., He, Y.-F., 2014. Evidence for nitrite-dependent anaerobic methane oxidation as a previously overlooked microbial methane sink in wetlands. Proc. Natl. Acad. Sci. U. S. A. 111, 4495-4500. http://dx.doi.org/10.1073/pnas.1318393111.

Huettel, M., Berg, P., Kostka, J.E., 2014. Benthic exchange and biogeochemical cycling in permeable sediments. Annu. Rev. Mar. Sci. 6, 23-51. http://dx.doi.org/10.1146/annurev-marine-051413012706.

Islas-Lima, S., Thalasso, F., Gomez-Hernandez, J., 2004. Evidence of anoxic methane oxidation coupled to denitrification. Water Res. 38, 13-16. http://dx.doi.org/10.1016/j.watres.2003.08.024.

Jørgensen, B.B., 2011. Deep subseafloor microbial cells on physiological standby. Proc. Natl. Acad. Sci. U. S. A. 108, 18193-18194. http://dx.doi.org/10.1073/pnas.1115421108.

Jakobsen, R., Postma, D., 1999. Redox zoning, rates of sulfate reduction and interactions with Fereduction and methanogenesis in a shallow sandy aquifer Romo, Denmark. Geochim. Cosmochim. Acta 63, 137-151.

Joye, S.B., 2012. Microbiology. A piece of the methane puzzle. Nature 491, 538-539. Kaiser, K., Guggenberger, G., 2000. The role of DOM sorption to mineral surfaces in the preservation of organic matter in soils. Org. Geochem. 31, 711-725. http://dx.doi.org/10.1016/S01466380(00)00046-2.

Kalbitz, K., Solinger, S., Park, J.H., Michalzik, B., Matzner, E., 2000. Controls on the dynamics of dissolved organic matter in soils: a review. Soil Sci. 165, 277.

Kato, S., Hashimoto, K., Watanabe, K., 2012. Microbial interspecies electron transfer via electric currents through conductive minerals. Proc. Natl. Acad. Sci. U. S. A. 109, 10042-10046.

Kellerman, A.M., Dittmar, T., Kothawala, D.N., Tranvik, L.J., 2014. Chemodiversity of dissolved organic matter in lakes driven by climate and hydrology. Nat. Commun. 5, 3804.

Kirschke, S., Bousquet, P., Ciais, P., Saunois, M., Canadell, J.G., Dlugokencky, E.J., Bergamaschi, P., Bergmann, D., Blake, D.R., Bruhwiler, L., Cameron-Smith, P., Castaldi, S., Chevallier, F., Feng, L., Fraser, A., Heimann, M., Hodson, E.L., Houweling, S., Josse, B., Fraser, P.J., Krummel, P.B., Lamarque, J.-F., Langenfelds, R.L., Le Quere, C., Naik, V., O'doherty, S., Palmer, P.I., Pison, I., Plummer, D., Poulter, B., Prinn, R.G., Rigby, M., Ringeval, B., Santini, M., Schmidt, M., Shindell, D.T., Simpson, I.J., Spahni, R., Steele, L.P., Strode, S.A., Sudo, K., Szopa, S., Van Der Werf, G.R., Voulgarakis, A., Van Weele, M., Weiss, R.F., Williams, J.E., Zeng, G., 2013. Three decades of global methane sources and sinks. Nat. Geosci. 6, 813-823. http://dx.doi.org/10.1038/ngeo1955. 
Kleber, M., Eusterhues, K., Keiluweit, M., Mikutta, C., Mikutta, R., Nico, P.S., 2015. Chapter one Mineral-Organic associations: formation, properties, and relevance in soil environments. In: Donald, L.S. (Ed.), Advances in Agronomy. Academic Press.

Klueglein, N., Kappler, A., 2013. Abiotic oxidation of Fe(II) by reactive nitrogen species in cultures of the nitrate-reducing $\mathrm{Fe}(\mathrm{II})$ oxidizer Acidovorax sp. BoFeN1-questioning the existence of enzymatic Fe(II) oxidation. Geobiology 11, 180-190. http://dx.doi.org/10.1111/gbi.12019.

Kluepfel, L., Piepenbrock, A., Kappler, A., Sander, M., 2014. Humic substances as fully regenerable electron acceptors in recurrently anoxic environments. Nat. Geosci. 7, 195-200. http://dx.doi.org/10.1038/ngeo2084.

Kritzberg, E.S., Ekstrom, S.M., 2012. Increasing iron concentrations in surface waters - a factor behind brownification? Biogeosciences 9, 1465-1478. http://dx.doi.org/10.5194/bg-9-14652012.

LaRowe, D.E., Van Cappellen, P., 2011. Degradation of natural organic matter: a thermodynamic analysis. Geochim. Cosmochim. Acta 75, 2030-2042. http://dx.doi.org/10.1016/j.gca.2011.01.020.

LaRowe, D.E., Dale, A.W., Regnier, P., 2008. A thermodynamic analysis of the anaerobic oxidation of methane in marine sediments. Geobiology 6, 436-449. http://dx.doi.org/10.1111/j.14724669.2008.00170.x.

LaRowe, D.E., Dale, A.W., Amend, J.P., Van Cappellen, P., 2012. Thermodynamic limitations on microbially catalyzed reaction rates. Geochim. Cosmochim. Acta 90, 96-109. http://dx.doi.org/10.1016/j.gca.2012.05.011.

Lalonde, K., Mucci, A., Ouellet, A., Gélinas, Y., 2012. Preservation of organic matter in sediments promoted by iron. Nature 483, 198-200.

Larese-Casanova, P., Scherer, M.M., 2007. Fe(II) sorption on hematite: new insights based on spectroscopic measurements. Environ. Sci. Technol. 41, 471-477. http://dx.doi.org/10.1021/es0617035.

Larsen, S., Nielsen, L.P., Schramm, A., 2015. Cable bacteria associated with long-distance electron transport in New England salt marsh sediment. Environ. Microbiol. Rep. 7, 175-179. http://dx.doi.org/10.1111/1758-2229.12216.

Lau, K.E.M., Washington, V.J., Fan, V., Neale, M.W., Lear, G., Curran, J., Lewis, G.D., 2015a. A novel bacterial community index to assess stream ecological health. Freshw. Biol. 60, 19882002. http://dx.doi.org/10.1111/fwb.12625.

Lau, M.P., Sander, M., Gelbrecht, J., Hupfer, M., 2015b. Solid phases as important electron acceptors in freshwater organic sediments. Biogeochemistry 123, 49-61. http://dx.doi.org/10.1007/s10533-014-0052-5.

Lau, M.P., Sander, M., Gelbrecht, J., Hupfer, M., 2016. Spatiotemporal redox dynamics in a freshwater lake sediment under alternating oxygen availabilities: combined analyses of dissolved and particulate electron acceptors. Environ. Chem. 13, 826-837. http://dx.doi.org/10.1071/EN15217.

Lau, M.P., Hupfer, M., Grossart, H.-P., 2017. Reduction-oxidation cycles of organic matter increase bacterial activity in the pelagic oxycline. Environ. Microbiol. Rep. 9, 257-267. http://dx.doi.org/10.1111/1758-2229.12526.

Leibold, M.A., Holyoak, M., Mouquet, N., Amarasekare, P., Chase, J.M., Hoopes, M.F., Holt, R.D., Shurin, J.B., Law, R., Tilman, D., Loreau, M., Gonzalez, A., 2004. The metacommunity concept: a framework for multi-scale community ecology. Ecol. Lett. 7, 601-613. http://dx.doi.org/10.1111/j.1461-0248.2004.00608.x.

Lennon, J.T., Cottingham, K.L., 2008. Microbial productivity in variable resource environments. Ecology 89, 1001-1014. http://dx.doi.org/10.1890/07-1380.1. 
Lever, M.A., Rogers, K.L., Lloyd, K.G., Overmann, J., Schink, B., Thauer, R.K., Hoehler T.M.Jørgensen, B.B., 2015. Life under extreme energy limitation: a synthesis of laboratoryand field-based investigations. FEMS Microbiol. Rev. 39, 688-728.

Lewandowski, Z., Beyenal, H., 2007. Fundamentals of Biofilm Research. CRC Press, London Boca Raton.

Lewandowski, J., Laskov, C., Hupfer, M., 2007. The relationship between Chironoms plumosus burrows and the spatial distribution of pore-water phosphate, iron and ammonium in lake sediments. Freshw. Biol. 52, 331-343. http://dx.doi.org/10.1111/j.1365-2427.2006.01702.x.

Li, Y., Yu, S., Strong, J., Wang, H., 2012. Are the biogeochemical cycles of carbon, nitrogen, sulfur, and phosphorus driven by the FeIII-FeII redox wheel in dynamic redox environments? J. Soils Sediments 12, 683-693. http://dx.doi.org/10.1007/s11368-012-0507-z.

Lovley, D.R., Coates, J.D., Blunt-Harris, E.L., Phillips, E.J., Woodward, J.C., 1996. Humic substances as electron acceptors for microbial respiration. Nature 382, 445-448.

Lovley, D.R., 1993. Dissimilatory metal reduction. Annu. Rev. Microbiol. 47, 263-290. http://dx.doi.org/10.1146/annurev.mi.47.100193.001403.

Lozupone, C.A., Knight, R., 2007. Global patterns in bacterial diversity. Proc. Natl. Acad. Sci. U. S. A. 104, 11436-11440. http://dx.doi.org/10.1073/pnas.0611525104.

Malvankar, N.S., Lovley, D.R., 2012. Microbial nanowires: a new paradigm for biological electron transfer and bioelectronics. ChemSusChem 5, 1039-1046.

Marion, A., Nikora, V., Puijalon, S., Bouma, T., Koll, K., Ballio, F., Tait, S., Zaramella, M., Sukhodolov, A., O'hare, M., Wharton, G., Aberle, J., Tregnaghi, M., Davies, P., Nepf, H., Parker G.Statzner, B., 2014. Aquatic interfaces: a hydrodynamic and ecological perspective. J. Hydraul. Res. 52, 744-758.

Marlow, J.J., Larowe, D.E., Ehlmann, B.L., Amend, J.P., Orphan, V.J., 2014. The potential for biologically catalyzed anaerobic methane oxidation on ancient mars. Astrobiology 14, 292 307. http://dx.doi.org/10.1089/ast.2013.1078.

Marsili, E., Baron, D.B., Shikhare, I.D., Coursolle, D., Gralnick, J.A., Bond, D.R., 2008. Shewanella secretes flavins that mediate extracellular electron transfer. Proc. Natl. Acad. Sci. U. S. A. 105, 3968-3973.

Marterns, C.S., Berner, R.A., 1974. Methane production in interstitial waters of sulfatedepleted marine sediments. Science 1985, 1167-1169.

Martinez, C., Alvarez, L., Celis, L., Cervantes, F., 2013. Humus-reducing microorganisms and their valuable contribution in environmental processes. Appl. Microbiol. Biotechnol. 97, 1029310308. http://dx.doi.org/10.1007/s00253-013-5350-7.

Marx, V., 2017. Microbiology: the return of culture. Nat. Methods 14 (1), 37-40. http://dx.doi.org/10.1038/nmeth.4107.

Marzocchi, U., Trojan, D., Larsen, S., Louise Meyer, R., Peter Revsbech, N., Schramm, A., Peter Nielsen, L., Risgaard-Petersen, N., 2014. Electric coupling between distant nitrate reduction and sulfide oxidation in marine sediment. ISME J. 8, 16821690.http://dx.doi.org/10.1038/ismej.2014.19.

Mayer, L.M., Schick, L.L., Hardy, K.R., Wagai, R., Mccarthy, J., 2004. Organic matter in small mesopores in sediments and soils. Geochim. Cosmochim. Acta 68, 3863-3872. http://dx.doi.org/10.1016/j.gca.2004.03.019.

McClain, M.E., Boyer, E.W., Dent, C.L., Gergel, S.E., Grimm, N.B., Groffman, P.M., Hart, S.C., Harvey, J.W., Johnston, C.A., Mayorga, E., McDowell, W.H., Pinay, G., 2003.

Biogeochemical hot spots and hot moments at the interface of terrestrial and aquatic ecosystems. Ecosystems 6, 301-312. http://dx.doi.org/10.1007/s10021-003-0161-9. 
McDougald, D., Rice, S.A., Barraud, N., Steinberg, P.D., Kjelleberg, S., 2012. Should we stay or should we go: mechanisms and ecological consequences for biofilm dispersal. Nat. Rev. Microbiol. 10, 39-50.

Megonigal, J.P., Hines, M., Visscher, P., 2003. 8.08 - Anaerobic metabolism: linkages to trace gases and aerobic processes. In: Holland, H.D., Turekian, K.K. (Eds.), Treatise on Geochemistry. Oxford, Pergamon.

Melton, E.D., Swanner, E.D., Behrens, S., Schmidt, C., Kappler, A., 2014. The interplay of microbially mediated and abiotic reactions in the biogeochemical Fe cycle. Nat. Rev. Microbiol. 12, 797-808. http://dx.doi.org/10.1038/nrmicro3347.

Miller, L.G., Baesman, S.M., Carlstroem, C.I., Coates, J.D., Oremland, R.S., 2014. Methane oxidation linked to chlorite dismutation. Front. Microbiol. 5. http://dx.doi.org/10.3389/fmicb.2014.00275.

Milucka, J., Ferdelman, T.G., Polerecky, L., Franzke, D., Wegener, G., Schmid, M., Lieberwirth, I., Wagner, M., Widdel, F., Kuypers, M.M.M., 2012. Zero-valent Sulphur is a key intermediate in marine methane oxidation. Nature 491, 541. http://dx.doi.org/10.1038/nature11656.

Moran, J.J., Beal, E.J., Vrentas, J.M., Orphan, V.J., Freeman, K.H., House, C.H., 2008. Methyl sulfides as intermediates in the anaerobic oxidation of methane. Environ. Microbiol. 10, 162173. http://dx.doi.org/10.1111/j.1462-2920.2007.01441.x.

Morono, Y., Terada, T., Nishizawa, M., Ito, M., Hillion, F., Takahata, N., Sano, Y., Inagaki, F., 2011. Carbon and nitrogen assimilation in deep subseafloor microbial cells. Proc. Natl. Acad. Sci. U. S. A. 108, 18295-18300. http://dx.doi.org/10.1073/pnas.1107763108.

Mulholland, P.J., Helton, A.M., Poole, G.C., Hall, R.O., Hamilton, S.K., Peterson, B.J., Tank, J.L., Ashkenas, L.R., Cooper, L.W., Dahm, C.N., Dodds, W.K., Findlay, S.E.G., Gregory, S.V., Grimm, N.B., Johnson, S.L., McDowell, W.H., Meyer, J.L., Valett, H.M., Webster, J.R., Arango, C.P., Beaulieu, J.J., Bernot, M.J., Burgin, A.J., Crenshaw, C.L., Johnson, L.T., Niederlehner, B.R., O/'Brien, J.M., Potter, J.D., Sheibley, R.W., Sobota, D.J., Thomas, S.M., 2008. Stream denitrification across biomes and its response to anthropogenic nitrate loading. Nature 452, 202-205.

Nevin, K.P., Lovley, D.R., 2002. Mechanisms for Fe (III) oxide reduction in sedimentary environments. Geomicrobiol. J. 19, 141-159.

Nielsen, L.P., Risgaard-Petersen, N., Fossing, H., Christensen, P.B., Sayama, M., 2010. Electric currents couple spatially separated biogeochemical processes in marine sediment. Nature 463, 1071-1074.

Nisbet, E.G., Dlugokencky, E.J., Bousquet, P., 2014. Methane on the rise-again. Science 343, $493-$ 495. http://dx.doi.org/10.1126/science.1247828.

Nordi, K.A., Thamdrup, B., 2014. Nitrate-dependent anaerobic methane oxidation in a freshwater sediment. Geochim. Cosmochim. Acta 132, 141-150. http://dx.doi.org/10.1016/j.gca.2014.01.032.

Nordi, K.A., Thamdrup, B., Schubert, C.J., 2013. Anaerobic oxidation of methane in an iron-rich Danish freshwater lake sediment. Limnol. Oceanogr. 58, 546-554. http://dx.doi.org/10.4319/lo.2013.58.2.0546.

Normark, S., 2015. Introducing npj biofilms and microbiomes. npj Biofilms Microbiomes , 15004.

Pallud, C., Van Cappellen, P., 2006. Kinetics of microbial sulfate reduction in estuarine sediments. Geochim. Cosmochim. Acta 70, 1148-1162. http://dx.doi.org/10.1016/j.gca.2005.11.002.

Payne, E.K., Burgin, A.J., Hamilton, S.K., 2009. Sediment nitrate manipulation using porewater equilibrators reveals potential for $\mathrm{N}$ and $\mathrm{S}$ coupling in freshwaters. Aquat. Microb. Ecol. 54, 233-241. 
Pedersen, L.L., Smets, B.F., Dechesne, A., 2015. Measuring biogeochemical heterogeneity at the micro scale in soils and sediments. Soil Biol. Biochem. 90, 122-138. http://dx.doi.org/10.1016/j.soilbio.2015.08.003.

Peralta, A.L., Ludmer, S., Kent, A.D., 2013. Hydrologic history influences microbial community composition and nitrogen cycling under experimental drying/wetting treatments. Soil Biol. Biochem. 66, 29-37. http://dx.doi.org/10.1016/j.soilbio.2013.06.019.

Pfeffer, C., Larsen, S., Song, J., Dong, M., Besenbacher, F., Meyer, R.L., Kjeldsen, K.U., Schreiber, L., Gorby, Y.A., El-Naggar, M.Y., Leung, K.M., Schramm, A., Risgaard- Petersen, N., Nielsen, L.P., 2012. Filamentous bacteria transport electrons over centimeter distances. Nature 491, 218-221.

Philippot, L., Raaijmakers, J.M., Lemanceau, P., Van Der Putten, W.H., 2013. Going back to the roots: the microbial ecology of the rhizosphere. Nat. Rev. Microbiol. 11, 789-799. http://dx.doi.org/10.1038/nrmicro3109.

Postma, D., Jakobsen, R., 1996. Redox zonation: equilibrium constraints on the Fe(III)/ SO4-reduction interface. Geochim. Cosmochim. Acta 60, 3169-3175. http://dx.doi.org/10.1016/00167037(96)00156-1.

Poulton, S.W., Krom, M.D., Raiswell, R., 2004. A revised scheme for the reactivity of iron (oxyhydr)oxide minerals towards dissolved sulfide. Geochim. Cosmochim. Acta 68, 37033715. http://dx.doi.org/10.1016/j.gca.2004.03.012.

Raghoebarsing, A.A., Pol, A., Van De Pas-Schoonen, K.T., Smolders, A.J.P., Ettwig, K.F., Rijpstra, W.I.C., Schouten, S., Damste, J.S.S., Op Den Camp, H.J.M., Jetten, M.S.M., Strous, M., 2006. A microbial consortium couples anaerobic methane oxidation to denitrification. Nature 440, 918-921. http://dx.doi.org/10.1038/nature04617.

Ranjard, L., Richaume, A., 2001. Quantitative and qualitative microscale distribution of bacteria in soil. Res. Microbiol. 152, 707-716. http://dx.doi.org/10.1016/S0923-2508(01)01251-7.

Reeburgh, W.S., 2007. Oceanic methane biogeochemistry. Chem. Rev. 107, 486-513. http://dx.doi.org/10.1021/cr050362v.

Reed, H.E., Martiny, J.B.H., 2013. Microbial composition affects the functioning of estuarine sediments. ISME J. 7, 868-879.

Reguera, G., McCarthy, K.D., Mehta, T., Nicoll, J.S., Tuominen, M.T., Lovley, D.R., 2005. Extracellular electron transfer via microbial nanowires. Nature 435, 1098-1101. http://dx.doi.org/10.1038/nature03661.

Richardson, D.J., Butt, J.N., Fredrickson, J.K., Zachara, J.M., Shi, L., Edwards, M.J., White, G., Baiden, N., Gates, A.J., Marritt, S.J., Clarke, T.A., 2012. The 'porin- cytochrome' model for microbe-to-mineral electron transfer. Mol. Microbiol. 85, 201-212. http://dx.doi.org/10.1111/j.1365-2958.2012.08088.x.

Rickard, D., Luther, G.W., 2007. Chemistry of iron sulfides. Chem. Rev. 107, 514-562. http://dx.doi.org/10.1021/cr0503658.

Rickard, D., Morse, J.W., 2005. Acid volatile sulfide (AVS). Mar. Chem. 97, 141-197. http://dx.doi.org/10.1016/j.marchem.2005.08.004.

Riedel, T., Biester, H., Dittmar, T., 2012. Molecular fractionation of dissolved organic matter with metal salts. Environ. Sci. Technol. 46, 4419-4426. http://dx.doi.org/10.1021/es203901u.

Riedel, T., Zak, D., Biester, H., Dittmar, T., 2013. Iron traps terrestrially derived dissolved organic matter at redox interfaces. Proc. Natl. Acad. Sci. U. S. A. 110 10101-10101.

Risgaard-Petersen, N., Revil, A., Meister, P., Nielsen, L.P., 2012. Sulfur, iron-, and calcium cycling associated with natural electric currents running through marine sediment. Geochim. Cosmochim. Acta 92, 1-13. http://dx.doi.org/10.1016/j.gca.2012.05.036. 
Roden, E.E., Kappler, A., Bauer, I., Jiang, J., Paul, A., Stoesser, R., Konishi, H., Xu, H., 2010. Extracellular electron transfer through microbial reduction of solid-phase humic substances. Nat. Geosci. 3, 417-421. http://dx.doi.org/10.1038/ngeo870.

Sander, M., Hofstetter, T.B., Gorski, C.A., 2015. Electrochemical analyses of redox-active iron minerals: a review of nonmediated and mediated approaches. Environ. Sci.Technol. 49 (10), 5862-5878. http://dx.doi.org/10.1021/acs.est.5b00006.

Schauer, R., Risgaard-Petersen, N., Kjeldsen, K.U., Tataru Bjerg, J.J., Jorgensen, B.B., Schramm, A., Nielsen, L.P., 2014. Succession of cable bacteria and electric currents in marine sediment. ISME J. 8, 1314-1322. http://dx.doi.org/10.1038/ismej.2013.239.

Scheller, S., Yu, H., Chadwick, G.L., McGlynn, S.E., Orphan, V.J., 2016. Artificial electron acceptors decouple archaeal methane oxidation from sulfate reduction. Science 351, 703-707. http://dx.doi.org/10.1126/science.aad7154.

Schlesinger, W.H., 2005. Biogeochemistry. Gulf Professional Publishing, Houston, TX, USA.

Schmidt, J.L., Deming, J.W., Jumars, P.A., Keil, R.G., 1998. Constancy of bacterial abundance in surficial marine sediments. Limnol. Oceanogr. 43, 976-982. http://dx.doi.org/10.4319/lo.1998.43.5.0976.

Schmidt, M.W.I., Torn, M.S., Abiven, S., Dittmar, T., Guggenberger, G., Janssens, I.A., Kleber, M., Kögel-Knabner, I., Lehmann, J., Manning, DaC., 2011. Persistence of soil organic matter as an ecosystem property. Nature 478, 49-56.

Scott, D.T., McKnight, D.M., Blunt-Harris, E.L., Kolesar, S.E., Lovley, D.R., 1998. Quinone moieties act as electron acceptors in the reduction of humic substances by humicsreducing microorganisms. Environ. Sci. Technol. 32, 2984-2989.

Segarra, K.E.A., Comerford, C., Slaughter, J., Joye, S.B., 2013. Impact of electron acceptor availability on the anaerobic oxidation of methane in coastal freshwater and brackish wetland sediments. Geochim. Cosmochim. Acta 115, 15-30. http://dx.doi.org/10.1016/j.gca.2013.03.029.

Segarra, K.E.A., Schubotz, F., Samarkin, V., Yoshinaga, M.Y., Hinrichs, K.-Y., Joye, S.B., 2015. High rates of anaerobic methane oxidation in freshwater wetlands reduce potential atmospheric methane emissions. Nat. Commun. 6, 7477. http://dx.doi.org/10.1038/ncomms8477.

Sigee, D.C., 2005. Freshwater Microbiology: Biodiversity and Dynamic Interactions of Microorganisms in the Aquatic Environment 2005 John Wiley \& Sons Ltd., Hoboken, NJ, USA (1s68-176).

Sivan, O., Adler, M., Pearson, A., Gelman, F., Bar-Or, I., John, S.G., Eckert, W., 2011. Geochemical evidence for iron-mediated anaerobic oxidation of methane. Limnol. Oceanogr. 56, 15361544. http://dx.doi.org/10.4319/lo.2011.56.4.1536.

Sivan, O., Antler, G., Turchyn, A.V., Marlow, J.J., Orphan, V.J., 2014. Iron oxides stimulate sulfatedriven anaerobic methane oxidation in seeps. Proc. Natl. Acad. Sci. U. S. A. 111, E4139E4147. http://dx.doi.org/10.1073/pnas.1412269111.

Smemo, K.A., Yavitt, J.B., 2007. Evidence for anaerobic CH4 oxidation in freshwater peatlands. Geomicrobiol. J. 24, 583-597. http://dx.doi.org/10.1080/01490450701672083.

Smemo, K.A., Yavitt, J.B., 2011. Anaerobic oxidation of methane: an underappreciated aspect of methane cycling in peatland ecosystems? Biogeosciences 8, 779793.http://dx.doi.org/10.5194/bg-8-779-2011.

Smith, H.J., Schmit, A., Foster, R., Littman, S., Kuypers, M.M.M., Foreman, C.M., 2016. Biofilms on glacial surfaces: hotspots for biological activity. npj Biofilms Microbiomes 2, 16008. http://dx.doi.org/10.1038/npjbiofilms.2016.8. 
Snider, R.M., Strycharz-Glaven, S.M., Tsoi, S.D., Erickson, J.S., Tender, L.M., 2012. Longrange electron transport in Geobacter sulfurreducens biofilms is redox gradientdriven. Proc. Natl. Acad. Sci. U. S. A. 109, 15467-15472.

Stoodley, P., Boyle, J.D., Lappin-Scott, H.M., 1999. Influence of flow on the structure of bacterial biofilms. In: Bell, C.R., Brylinsky, M., Johnson-Green, P.C. (Eds.), Microbial Biosystems: New Frontiers: Proceedings of the 8th International Symposium on Microbial Ecology. Atlantic Canada Society for Microbial Ecology. pp. 263-269.

Strayer, D.L., Power, M.E., Fagan, W.F., Pickett, S.T.A., Belnap, J., 2003. A classification of ecological boundaries. Bioscience 53http://dx.doi.org/10.1641/00063568(2003)053[0723:acoeb]2.0.co;2. (723-723).

Strickland, M.S., Lauber, C., Fierer, N., Bradford, M.A., 2009. Testing the functional significance of microbial community composition. Ecology 90, 441-451. http://dx.doi.org/10.1890/080296.1.

Thamdrup, B., 2000. Bacterial manganese and iron reduction in aquatic sediments. Adv. Microb. Ecol. $16,41-84$.

Thauer, R.K., Shima, S., 2008. Methane as fuel for anaerobic microorganisms. Ann. N. Y. Acad. Sci. 1125.1 (2008), 158-170.

Thauer, R.K., 2010. Functionalization of methane in anaerobic microorganisms. Angew. Chem. Int. Ed. 49, 6712-6713. http://dx.doi.org/10.1002/anie.201002967.

Timmers, P.H., Suarez-Zuluaga, D.A., Van Rossem, M., Diender, M., Stams, A.J., Plugge, C.M., 2016. Anaerobic oxidation of methane associated with sulfate reduction in a natural freshwater gas source. ISME J. 10, 1400-1412. http://dx.doi.org/10.1038/ismej.2015.213.

Torres, I.C., Inglett, K.S., Reddy, K.R., 2011. Heterotrophic microbial activity in lake sediments: effects of organic electron donors. Biogeochemistry 104, 165-181. http://dx.doi.org/10.1007/s10533-010-9494-6.

Tratnyek, P.G., Grundl, T.J., Haderlein, S.B., 2011. Aquatic Redox Chemistry. American Chemical Society Washington, DC.

Trouwborst, R.E., Clement, B.G., Tebo, B.M., Glazer, B.T., Luther, G.W., 2006. Soluble Mn (III) in suboxic zones. Science 313, 1955-1957. http://dx.doi.org/10.1126/science.1132876.

Valentine, D.L., Reeburgh, W.S., 2000. New perspectives on anaerobic methane oxidation. Environ. Microbiol. 2, 477-484.

Valentine, D.L., 2002. Biogeochemistry and microbial ecology of methane oxidation in anoxic environments: a review. Anton. Leeuw. Int. J. G. 81, 271-282. http://dx.doi.org/10.1023/a:1020587206351.

Valenzuela, E.I., Prieto-Davó, A., López-Lozano, N.E., Hernández-Eligio, A., Vega- Alvarado, L., Juárez, K., García-González, A.S., López, M.G., Cervantes, F.J., 2017. Anaerobic methane oxidation driven by microbial reduction of natural organic matter in a tropical wetland. Appl. Environ. Microbiol. 17, 83-94.

Vignaga, E., Sloan, D.M., Luo, X., Haynes, H., Phoenix, V.R., Sloan, W.T., 2013. Erosion of biofilmbound fluvial sediments. Nat. Geosci. 6, 770-774. http://dx.doi.org/10.1038/ngeo1891.

Vrede, K., 2005. Nutrient and temperature limitation of bacterioplankton growth in temperate lakes. Microb. Ecol. 49, 245-256. http://dx.doi.org/10.1007/s00248-004-0259-4.

Wagner, M., 2009. Single-cell ecophysiology of microbes as revealed by Raman microspectroscopy or secondary ion mass spectrometry imaging. Annu. Rev. Microbiol. 63, 411-429.

Wan, M., Shchukarev, A., Lohmayer, R., Planer-Friedrich, B., Peiffer, S., 2014. Occurrence of surface polysulfides during the interaction between ferric (Hydr)Oxides and aqueous sulfide. Environ. Sci. Technol. 48 (9), 5076-5084. http://dx.doi.org/10.1021/es405612f. 
Weber, K.A., Achenbach, L.A., Coates, J.D., 2006. Microorganisms pumping iron: anaerobic microbial iron oxidation and reduction. Nat. Rev. Microbiol. 4, 752-764.

Wegener, G., Krukenberg, V., Riedel, D., Tegetmeyer, H.E., Boetius, A., 2015. Intercellular wiring enables electron transfer between methanotrophic archaea and bacteria. Nature 526http://dx.doi.org/10.1038/nature15733. (587-U315).

Weng, L.P., Koopal, L.K., Hiemstra, T., Meeussen, J.C.L., Van Riemsdijk, W.H., 2005. Interactions of calcium and fulvic acid at the goethite-water interface. Geochim. Cosmochim. Acta 69, 325-339. http://dx.doi.org/10.1016/j.gca.2004.07.002.

Wilhelm, L., Singer, G.A., Fasching, C., Battin, T.J., Besemer, K., 2013. Microbial biodiversity in glacier-fed streams. ISME J. 7, 1651-1660. http://dx.doi.org/10.1038/ismej.2013.44.

Williams, A.G.B., Scherer, M.M., 2004. Spectroscopic evidence for Fe(II)-Fe(III) electron transfer at the iron oxide-water interface. Environ. Sci. Technol. 38, 47824790.http://dx.doi.org/10.1021/es049373g.

Wunderlin, T., Corella, J.P., Junier, T., Bueche, M., Loizeau, J.-L., Girardclos, S., Junier, P., 2014. Endospore-forming bacteria as new proxies to assess impact of eutrophication in Lake Geneva (Switzerland-France). Aquat. Sci. 76, 103-116. http://dx.doi.org/10.1007/s00027-013-0329-0.

Young, I.M., Crawford, J.W., Nunan, N., Otten, W., Spiers, A., 2008. Chapter 4 Microbial Distribution in Soils: Physics and Scaling. Advances in Agronomy. Academic Press.

Zehnder, A.J.B., Brock, T.D., 1980. Anaerobic methane oxidation-occurrence and ecology. Appl. Environ. Microbiol. 39, 194-204.

Zimmerman, A.R., Goyne, K.W., Chorover, J., Komarneni, S., Brantley, S.L., 2004. Mineral mesopore effects on nitrogenous organic matter adsorption. Org. Geochem. 35 (3), 355-375.

Zinger, L., Gobet, A., Pommier, T., 2012. Two decades of describing the unseen majority of aquatic microbial diversity. Mol. Ecol. 21, 1878-1896. http://dx.doi.org/10.1111/j.1365294X.2011.05362.x.

Zopfi, J., Böttcher, M.E., Jørgensen, B.B., 2008. Biogeochemistry of sulfur and iron in Thioplocacolonized surface sediments in the upwelling area off central chile. Geochim. Cosmochim. Acta 72, 827-843. http://dx.doi.org/10.1016/j.gca.2007.11.031. 


\section{Figures}

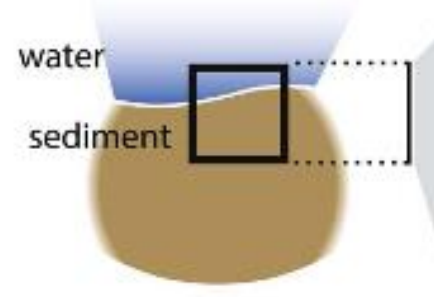

bulk interface

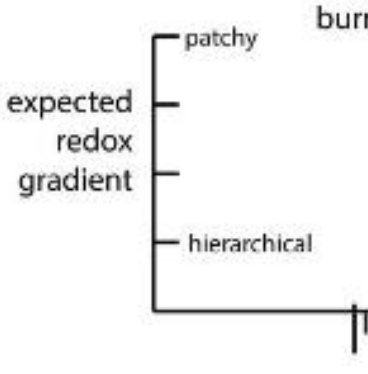

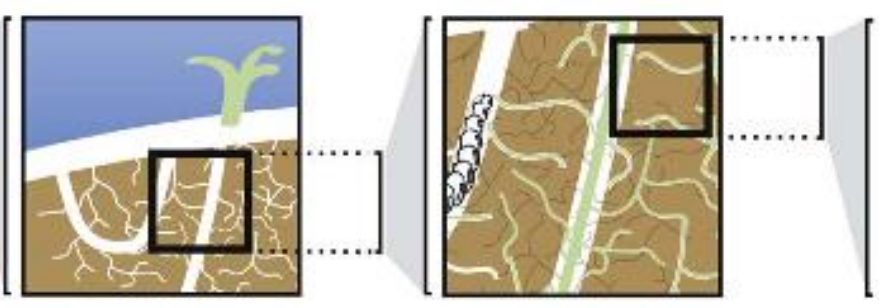

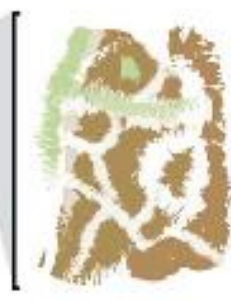

(macro-)biological structures root systems

particle surface traits cracks and pores biofilms

Figure 1

Conceptual visualization of the sediment-water interface across scales. Heterogeneities of different dimension can structure the redox environment at the interface. At coarse resolution, the redox gradient across the interface may seem hierarchical (featuring a decreasing reduction potential $E_{h}$ within creased distance from the interface). On smaller scales, however, biological and physical heterogeneities create a patchy and discontinuous framework of microsites dominated by redox processes running at different $E_{h}$. 


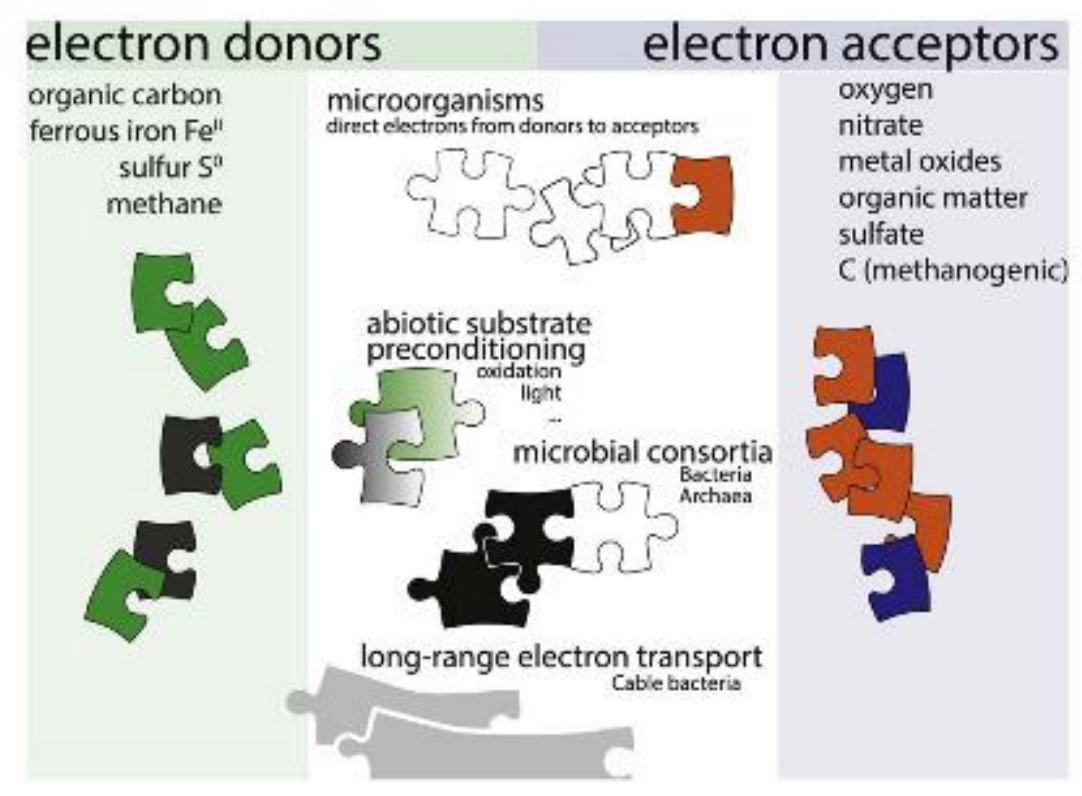

Figure 2

Microorganisms couple the oxidation of electron donors (reduced organic and inorganic species, left) to the oxidation of electron acceptors (oxygen to sulfate, and carbon in methanogenesis, right). The figure illustrates some of the extraordinary pathways that microorganisms take to acquire energy in directing electrons from donors to acceptors. These pathways include the co-metabolism in syntrophy with other microbial species, electron transfer over centimeter distances to bridge distant donor and acceptor reservoirs or abiotic transformations preceding metabolic accessibility. 